\title{
The Retablos of Teabo and Mani: The Evolution of Renaissance Altars in Colonial Yucatán
}

\author{
C. Cody Barteet
}

check for updates

Citation: Barteet, C. Cody. 2021. The Retablos of Teabo and Mani: The

Evolution of Renaissance Altars in

Colonial Yucatán. Arts 10: 23.

https://doi.org/10.3390/arts10020023

Academic Editor: Lauren Beck

Received: 9 February 2021

Accepted: 31 March 2021

Published: 6 April 2021

Publisher's Note: MDPI stays neutral with regard to jurisdictional claims in published maps and institutional affiliations.

Copyright: (C) 2021 by the author. Licensee MDPI, Basel, Switzerland. This article is an open access article distributed under the terms and conditions of the Creative Commons Attribution (CC BY) license (https:// creativecommons.org/licenses/by/ $4.0 /)$.
Department of Visual Arts, Western University, London, ON N6A 3K7, Canada; cbarteet@uwo.ca

\begin{abstract}
From the turn to seventeenth through the early eighteenth century, three retablos (altarpieces) were created in Yucatán that relied on a similar Renaissance design. The retablos located in the ex-convents of Mani and Teabo all adopt the Spanish sixteenth-century Renaissance style of the Plateresque. Further, the retablos are connected by the inclusion of caryatid framing devices that establishes a strong affinity among the works. Two of the retablos are located in Mani: the Retablo of San Antonio de Padua and the Retablo of Nuestra Señora de Soledad (or sometimes called the Dolores Retablo). At Teabo is the Retablo de Santa Teresita del Niño Jesús (or Las Ánimas). This paper explores the relationships among the retablos by considering their iconography and their styles to address the retablos' dates and their current locations. While offering insights about these retablos, this contribution also provides a rich discussion of the thriving artistic industry that was present in Yucatán.
\end{abstract}

Keywords: retablo; caryatids; Virutes; Plateresque; Renaissance; Teabo; Mani; Yucatán; La Soledad; Dolores; San Antonio; Las Ánimas; Crucifixion; Passion; Santa Teresita

\section{Introduction}

During the seventeenth and eighteenth centuries, the Yucatán peninsula experienced an unexpected boom in the production of retablos. For its three cathedrals (Campeche, Mérida, Valladolid) and its over 300 parishes and convents, close to two-hundred altarpieces were produced (Bolañas and Fernández 1945; Bretos 1987, 1992; Perry and Perry 1988). Outside of its major cities of Mérida, Valladolid, and Campeche, retablo construction is directly connected to shifts in agrarian production. By the close of the seventeenth century, economic imbalance increased alongside the concentration of wealth among the privileged creole class and the eventual development of haciendas in the eighteenth century. At its apogee from the mid-seventeenth through early eighteenth centuries, retablo production resulted in a flourishing artistic culture wherein tremendous diversity exists among the altarpieces, with very few appearing to have direct correlations with each other, whether in style or in composition. However, three retablos that are now housed in the historical region of the Maya province of Mani are undoubtedly connected to one another. The three altarpieces are the Retablo of San Antonio (Figure 1) and the Retablo of Nuestra Señora de La Soledad (sometimes referenced as the Dolores Retablo, Figure 2), both from the ex-convento of San Miguel de Arcángel in Mani, and the Retablo of Santa Teresita del Niño (or sometimes Las Ánimas) from the ex-convento of San Pedro y San Pablo at Teabo (Figure 3). Unlike other retablos in Yucatán, these three works have strong compositional design elements and stylistic characteristics that make them unique to Yucatán. Despite their clear similarities the works, like all retablos in Yucatán, are grossly understudied, which may be due in part to the significant lacuna of archival documentation still extant in Yucatán. ${ }^{1}$ sIn analyzing

1 The years post Mexican Independence led to the neglect and destruction of many parish and townhall records during the Caste Wars of the late nineteenth and early twentieth centuries. Frequently, religious sites were targeted and destroyed, including the cathedral in Mérida and the Mani convent (Ancona 1889, vol. 3). The fragmented materials that survive are typically legal records, but there are some church materials that are gathered today at the Archivo Histórico de la Arquidiócesis in Yucatán. Although spanning the whole of the colonial era, the documents are not complete. 
the retablos, my goal is to document the evolution of Yucatán's visual culture from the sixteenth to eighteenth centuries through these three altarpieces. This paper considers how Yucatecan peoples developed artistic practices that promoted regional specificity through frameworks for Indigenous and Spanish art practices.

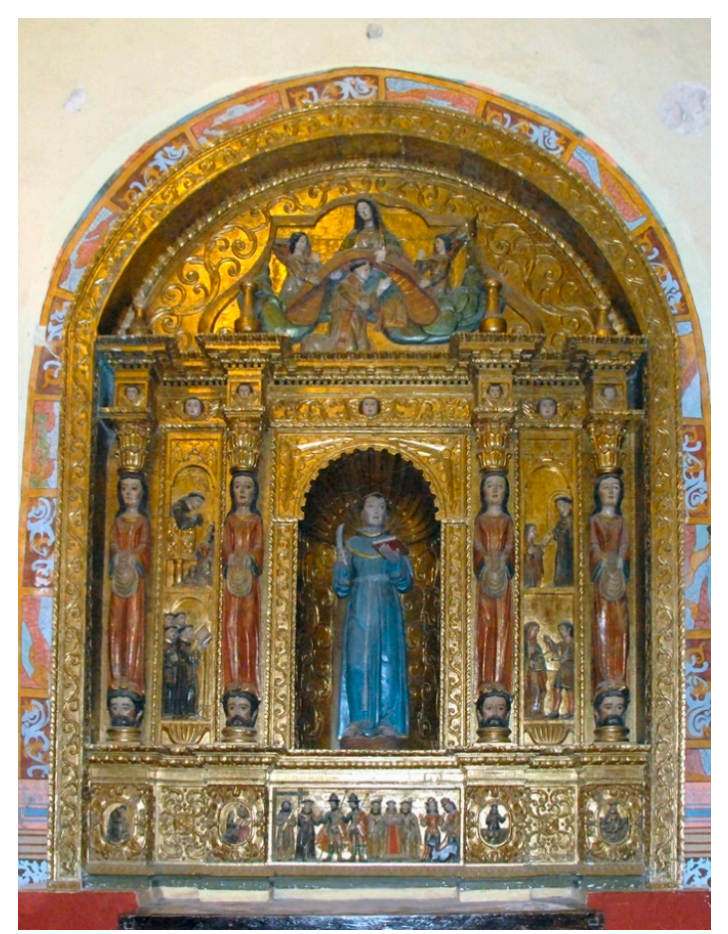

Figure 1. Retablo of San Antonio de Padua. Ex-convento of San Miguel de Arcángel, Mani, Yucatán, ca. eighteenth century. Photograph created by and used with Permission of Niccolò Brooker.

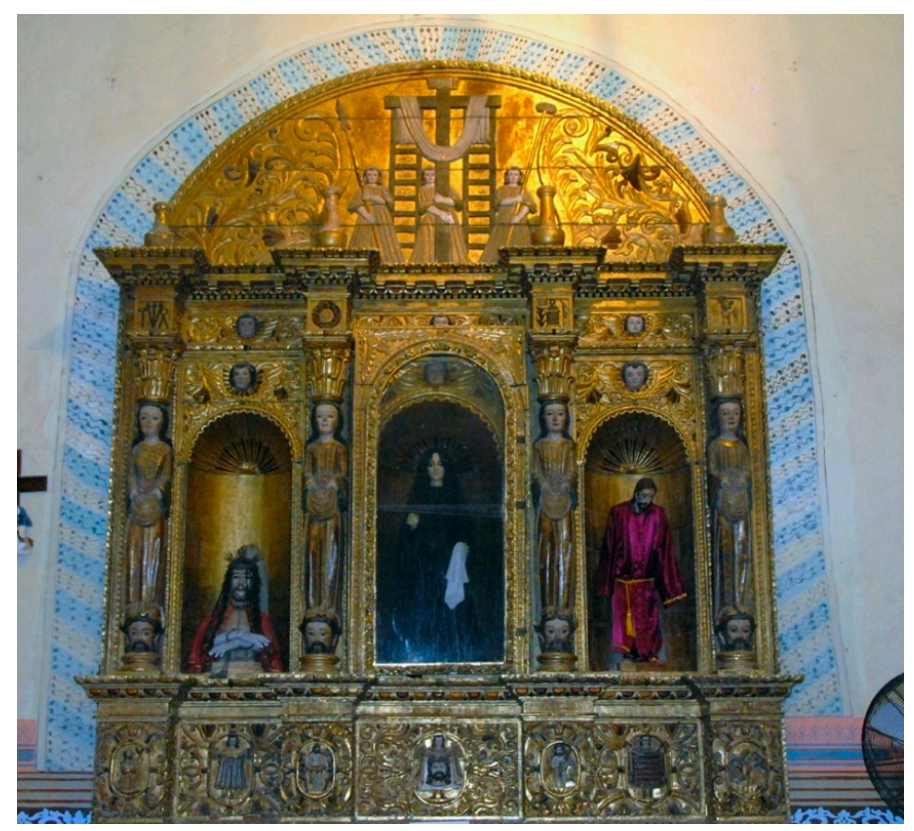

Figure 2. Retablo of Nuestra Señora de la Soledad. Ex-convento of San Miguel de Arcángel, Mani, Yucatán, ca. sixteenth to seventeenth centuries. Photograph created by and used with Permission of Niccolò Brooker. 


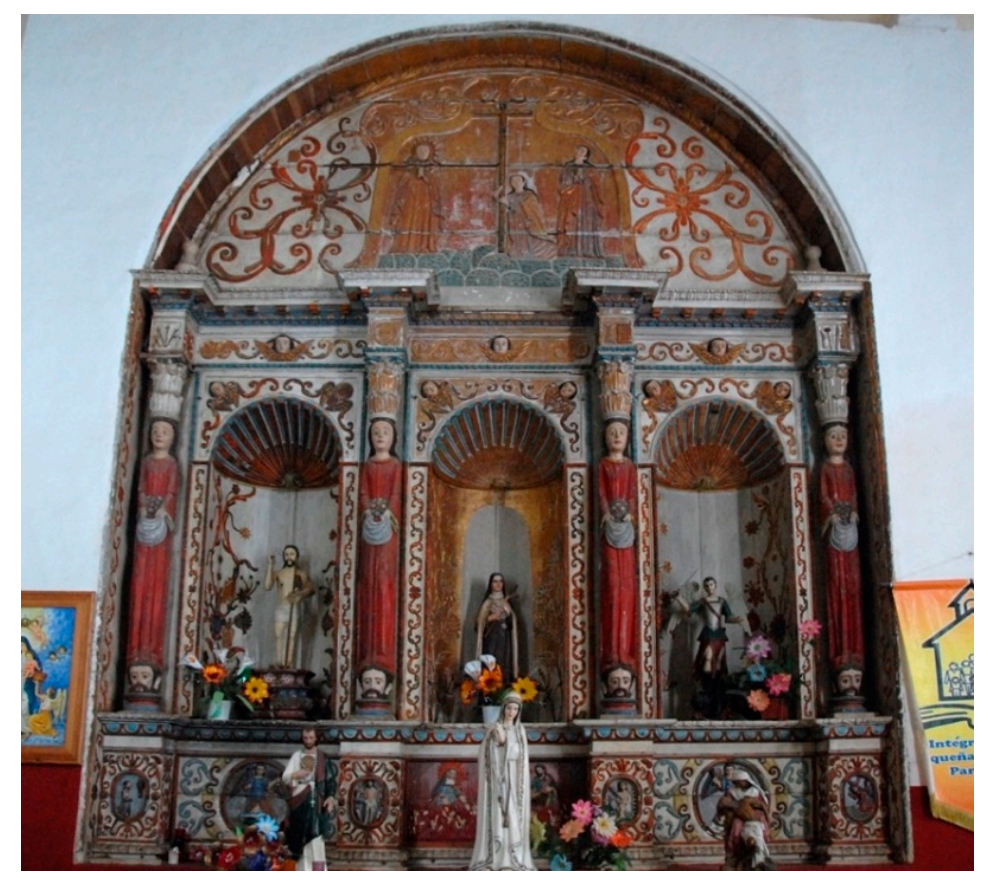

Figure 3. Retablo of Santa Teresita del Niño Jesús. Ex-convento of San Pedro y San Pablo, Teabo, Yucatán, ca. eighteenth century. Photograph created by and used with Permission of Niccolò Brooker.

Before analyzing the retablos, several points should be highlighted. First, although the altarpieces have similar appearances, they were not made at the same time (Pascacio Guillén 2021; Barteet Forthcoming). Each work is slightly different from the other. Likewise, none of the free-standing sculptures are original to the retablos (Pascacio Guillén 2021). The sculptures date from the seventeenth through the twentieth centuries. As it is not possible to account for the sculptures' original functions and locations, I will spend less time discussing these objects in comparison to the actual relief sculptures on the retablos. Additionally, the significant portions of some of the retablos have been repainted, including the white paint applied to the surface of the Santa Teresita del Niño Jesús retablo. Art historian Bertha Pascacio Guillén has suggested that the three retablos are not in situ (Pascacio Guillén 2021). Although I have not seen all the data from her unpublished dissertation or in our personal correspondence, and nor have either of us been able to access the unpublished INAH restoration reports, Pascacio Guillén's assumptions provide an interesting point for discussion about (Personal Communication 29 January 2021). Ultimately, I argue that the altarpieces date from the late sixteenth century through the eighteenth centuries. In doing so, I suggest that the La Soledad altarpiece, now present in Mani, was originally produced in a deeply symbolic Plateresque style for the now destroyed Convent of San Francisco in Mérida. Further, it seems that the retablo of San Antonio for Mani was made to replace the faded mural cycle of San Antonio there, but does so through the style of the La Soledad retablo; and finally, it appears that the retablo at Teabo is an eighteenth-century creation based on La Soledad's composition and iconography. While in part I agree with Pascacio Guillén's assertations that the La Soledad altarpiece was not sculpted for the ex-convento of San Miguel de Arcángel, I differ from her assertion that all three retablos were produced for the same monastery.

To explore these topics this paper is organized into two sections: The Retablos and The Discussion. The Retablos section will provide descriptive analyses for the three works: Retablo of Nuestra Señora de la Soledad, Retablo of San Antonio, and Retablo of Santa Teresita del Niño. The ensuing discussion will contextualize the artists, caryatids, dating, and locations for these retablos. 


\section{The Retablos}

The three retablos are located at the ex-conventos of San Miguel de Arcángel, Mani, and San Pedro y San Pablo in Teabo; the towns are approximately $100 \mathrm{~km}$ to the south-west of Mérida. Teabo and Mani are approximately $10 \mathrm{~km}$ apart and belong to the historical province of Mani. The province, which has its foundations in the pre-contact era, was once governed by the Xiu Maya. The Xiu were one of the over 200 clans active in Yucatán at the time of the Spanish conquest and the family allied with the Spanish during Yucatán's bloody colonization (Restall 2001; Quezada 1993, 2014). In the 1540s the lands fell under the Spanish dominion of Yucatán's first governor, Francisco de Montejo, who recognized the rich fertile lands as being among the most productive in all of Yucatán and inhabited by a large population of peoples who could work these fields (Cogolludo 1688). During the last half of the century, the Franciscans began to establish convents in the province's principal centers, including Mani and its dependent towns like Teabo. According to Fray Bernardo de Lizana, the new monastery at Mani was begun on 29 September 1549, and the bulk of the complex was completed some seven months later by six thousand Maya laborers who had adhered to the plans of Fray Juan de Mérida; the church and its convent were eventually completed in 1588 (Lizana 1983; Ciudad Real [1631] 1976; Cárdenas Valencia [1639] 1937; Suárez Castro 2014). The church's nave is decorated with seven retablos: the retablo mayor of San Miguel de Archangel; the south wall retablos of San Antonio and the Virgen de la Luz; and the north wall altars of La Soledad, La Asunción, Santa Lucía, and Sagrada Familia along with smaller altars in the sacristy and other alcoves of the church (Bolañas and Fernández 1945).

The current monastery at Teabo was not built until 1696 as indicated by a dedicatory plaque. This church likely replaced the original structure that was begun in 1609 based on Fray Diego Lopéz de Cogolludo's references in his 1688 text, Historia de Yucathan [sic]. The century of difference between the building likely explains the variations in their design despite their close geographic proximity: Mani adopts a simple single nave structure while Teabo is laid out with a nave and two flanking side aisles. As was common throughout the period, the churches were once painted with numerous frescoes, which, when combined with the retablos, created an immersive visual experience. For example, through the restoration programs at Mani during the early 2000s, it was discovered that several fresco cycles adorned the nave walls, which are presently covered by the retablos. In the niche that contains the San Antonio retablo, scenes of the saint's life appeared in the vault's upper arch, while behind the La Soledad altar, images from the miracles of San Diego de Alcalá were painted (Vanoye Carlo 2011, 2016). With these contexts in mind, a formal description of the retablos will follow.

\subsection{Retablo of Nuestra Señora de La Soledad}

Resting flat against the northern-nave wall of San Miguel is the La Soledad retablo (see Figure 2). The altarpiece adopts the popular Renaissance-era triumphal arch patterning. The arches, symmetrical in height and width are defined and separated by the four caryatids or female terms. The terms rise from a classical pedestal and support a large arched pediment. The caryatids frame three niches. Inside the niches are sculptures, none of which are original to the altarpiece. The largest of the three figures is a seventeenth-century sculpture that represents the suffering Virgin Mary (hence, the modern nickname of Nuestra Señora de los Dolores). The left niche contains a painted bust of a much smaller seventeenthcentury sculpture of the Ecce Homo that highlights the physical suffering of the bleeding, the bound, and the anguished Christ. An eighteenth-century processional sculpture of the suffering Christ is found in the left niche. The articulated sculpture's clothing can be changed to correspond to the Catholic calendar; in the image captured here, Christ wears a purple tunic that identifies him as the Mocked Christ, a pejorative troupe used to identify him as "The King of the Jews." The retablo culminates with a rounded pediment that displays an empty cross flanked by three female figures, a presumed reference to Christ's sacrifice, but also his triumph over death, in that of the empty cross (Figure 4). 


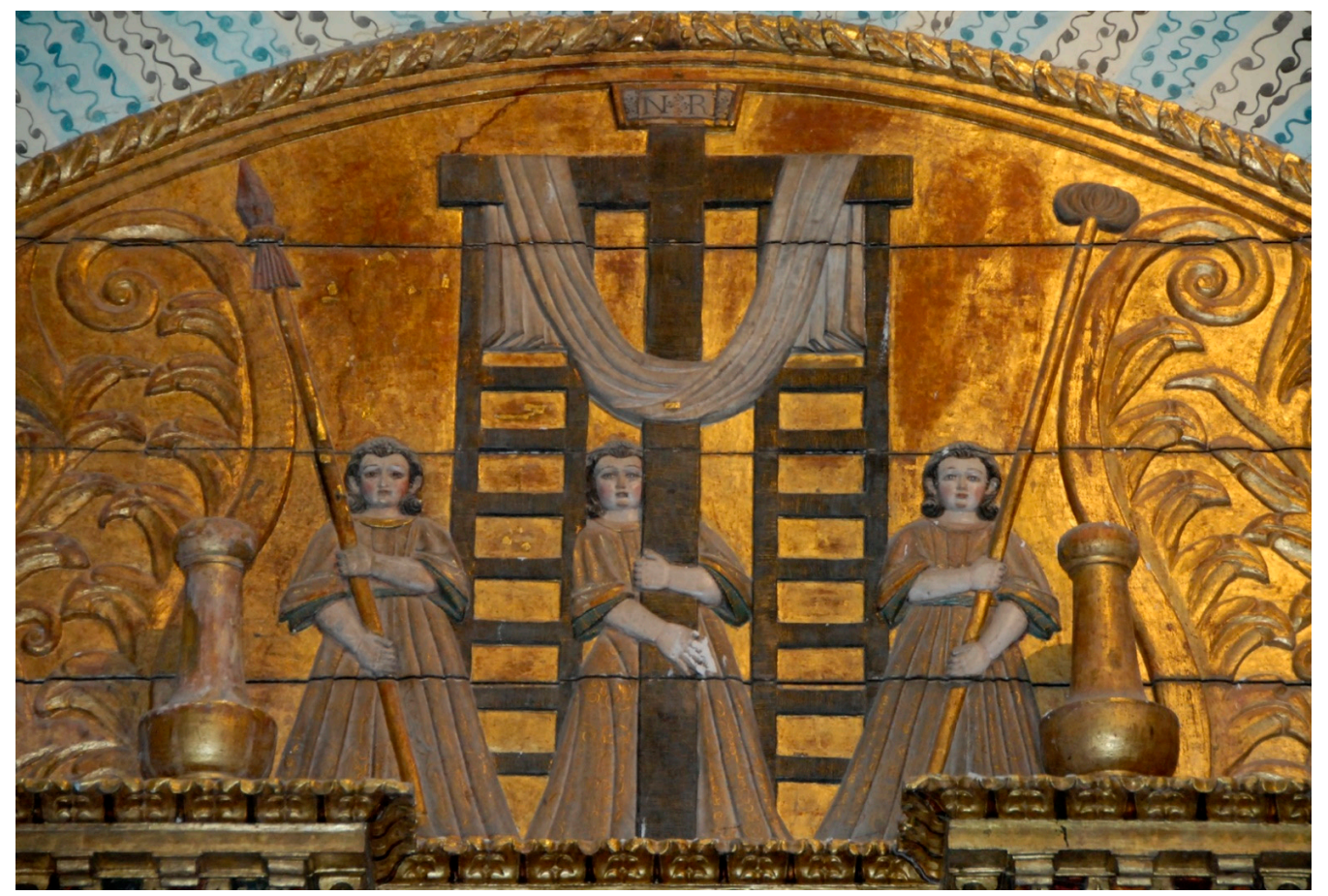

Figure 4. Detail, “The Cross with Three Angels." Retablo of Nuestra Señora de la Soledad. Photograph created by and used with Permission of Niccolò Brooker.

The retablo itself is sculpted with images associated with the Arma Christi, a term for the instruments used during Christ's Passion. The objects operate as mnemonic devices, to facilitate spiritual contemplation on the events leading to and immediately after Christ's Crucifixion. In viewing the images, devotees are inspired to consider their faithfulness to Christ; for example, will they deny him like Peter (rooster) or betray him for money like Judas (thirty-silver coins)? To mediate upon these and other issues, the retablo consists of eleven scenes.

The predella, or lower zone of the retablo, depicts seven of them. Each scene occupies its own medallion, and they are separated from each other by a series of dense foliage that are typical of the Plateresque. In this idiom, such imagery is a reminder of the struggles of civility and Christianity to overcome sin and deceit that exists in a world without salvation. Such concepts are present throughout secular and religious works in Spain including the retablos in Pajares, Cádiz, Valencia, and Galicia and on façades like the Universidad de Salamanca's or Hospital de Santa Cruz, Toledo or private residences like the Casa de Castril, Granada (Padrón Mérida 1993; Vila Jato 1987; Gómez-Ferrer and Celis 2012; Caramazana Malia and Bejarano 2020; Nieto Alcaide et al. 2009; Álvarez 2001; Barteet 2019). Whether secular or religious, dense foliage populated by grotesques, seraphim, wild men, and other fantastical creatures are often juxtaposed to larger and more discernable images of patrons, classical personas, and Christian iconography. The contrast between the sacred and profane with the grotesques and fantastical creatures is deliberate and conveys ideas about individual or communal self-representation, or as in the case of the retablos, they illuminate Christian theology, often centered on the Life of Christ and associated iconography to convey divine salvation through Christ's acts, preaching, death, and resurrection.

Similar contrasts appear in the predella scenes of the La Soledad retablo. At left is the "Agony in the Garden of Gethsemane" (Figure 5). The story, like all its companions, is paired down to its simplest elements: a kneeling Christ before a floating chalice-references to Jesus' pending sacrifice and an attribute of the sacrament of communion. The other scenes depicted on the retablo consist of "The Seamless Shroud," The Flagellation," "The Sudarium" or "Veil of Christ," "Ecce Homo," "The Thirty Pieces of Silver for Judas," and the "Carrying the Cross." 


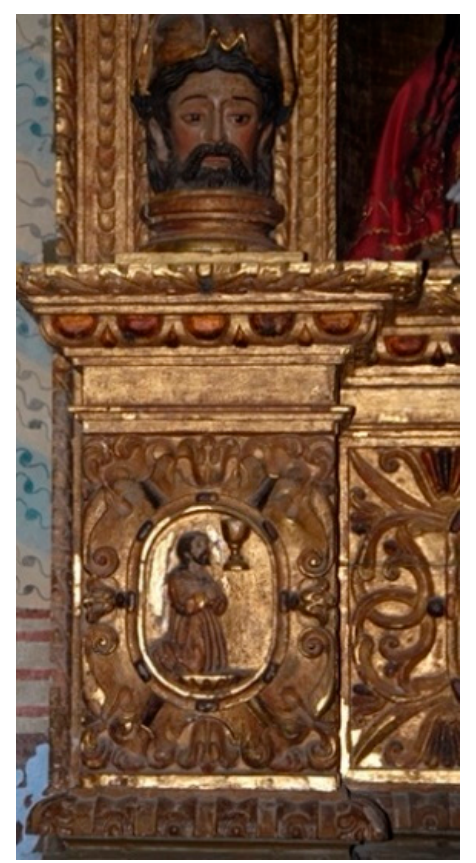

Figure 5. Detail, “Agony in the Garden of Gethsemane." Retablo of Nuestra Señora de la Soledad. Photograph created by and used with Permission of Niccolò Brooker.

Arising from the pedestal are the four terms that stand upon bearded male heads (Figure 6). The identical caryatids hold bags overflowing with some type of anemone. Each term wears long robes, and their heads are adorned by double stacked acanthus-style capitals indirectly based on the Erechtheion's Porch of Maidens (Athens, Acropolis). The capitals support impost blocks that are decorated with vignettes depicting further elements of the Passion narrative: at the far left "The Nails, the Pincers, and the Hammer," "The Crown of Thorns," "The Reed, the Box of Myrrh, the Lantern, and the Knife," and finally to the extreme right, "The Rooster Standing on a Column." ${ }^{2}$ The caryatids' placements create three symmetrical, arched vertical planes. Today, a glass frame, which is slightly taller than the original arch, has been placed over the central niche, thus disrupting the original symmetry. Each recessed area is scalloped at the top; above the arch are vertical planes and the architrave is slightly taller than the impost blocks between the four vignettes. Both vertical planes have winged cherubs on centerlines above the niches, common images found in Renaissance art.

The arched pediment is supported and separated from the central zone by the entablature's dentils. The large arched area depicts three figures and the Cross. The central figure embraces the Cross. The Cross terminates at plague with the Latin abbreviation INRI (Iesus Nazarenus Rex Iudaeorum)that identifies Christ as "Jesus the Nazarene, King of the Jews." ${ }^{3}$ From its crossbeam hangs the shroud given by Joseph of Arimathea to wrap the dead Christ. The central figure is separated visually from the others by two ladders that rest on the left and right sides of the Cross' crossbeam. The figure to the left holds the spear used by the Roman centurion Longinus while the right figure holds the staff topped by a sponge, which was dipped in the vinegar used to "quench" Christ's thirst.

2 Although I identify the box as that of the myrrh, more often there are representations of dice, which are a reminder of the Roman soldiers casting dice for lots of Christ's simple possessions.

3 Called the Titulus Crucis (Title of the Cross) the abbreviation of INRI derives from the Gospel of John vol. 19, pp. 19-20 which stated that the inscription was written in three languages: Hebrew, Latin, and Greek. 


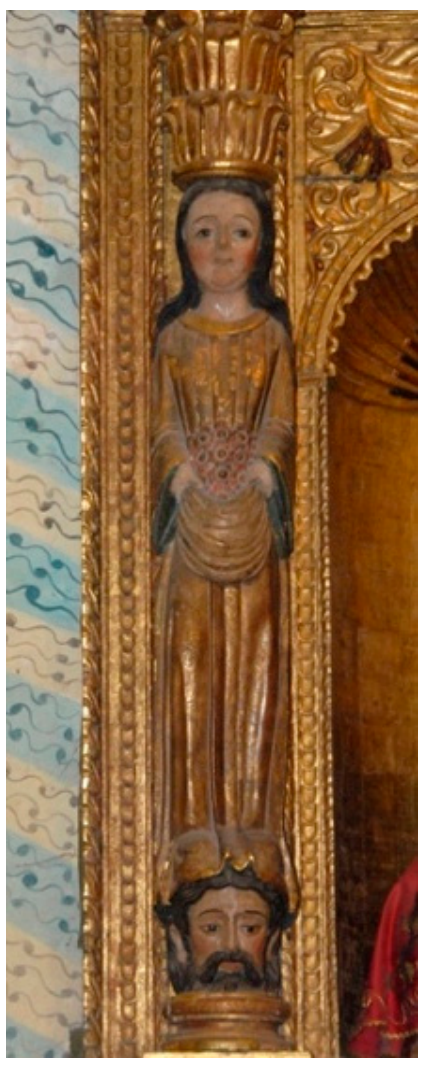

Figure 6. Detail, "Caryatid or Virtue." Retablo of Nuestra Señora de la Soledad. Photograph created by and used with Permission of Niccolò Brooker.

\subsection{Retablo of San Antonio de Padua}

Directly across the nave from La Soledad is the altar to San Antonio (see Figure 1). Like La Soledad, the Antonio retablo relies upon a Renaissance inspired patterning and triumphal arch design. Produced around the eighteenth century, the arched retable fills a shallow niche in the nave wall with scenes from the saint's life. In both the frescoes and on the retablo, the scenes depicted that are primarily those associated with Antonio's miraculous preaching, which undoubtedly reinforces why the narrative cycle was placed next to Mani's pulpit, or the site of the epistle (Figure 7). Unfortunately, I have only found one reproduction of the painted scene, "The Miracle of the Mule." In her doctoral thesis from 2011, Ana Raquel Vanoye Carlo included an oblique view of the scene (Vanoye Carlo 2011). Curiously, the few figures represented wear the same early modern style attire used on the retablo. In each work the men are dressed in similar hats, shirts, pants, robes, etc. Seemingly this suggests that when the sculptors crafted the retablo, they drew directly from the fading scenes of the San Antonio mural cycle.

In structure and design, the Antonio retablo corresponds to the visual aesthetic of the La Soledad altar. What is most compelling about this is the retablo's reliance on the Plateresque at such a late date. The style was popular in the first half of the sixteenth century in Europe and remained popular in Hispanic America through the whole of the century. Often the Plateresque allowed for continual adaptation and revision because of its rich aesthetic features that could accommodate the desires of patrons (McAndrew and Toussaint 1942). Such adaptability may explain its usage in the Antonio retablo. Like the La Soledad retablo, four caryatids standing upon bearded heads rise from the pedestal below. The terms again act as framing devices that establish three arched fields: two implied niches filled with relief panels flank a central niche that holds a large freestanding polychrome sculpture of the saint. Around the saint are multiple scenes from his life. The predella has five scenes, four of which are depicted in medallions: "The Anointing of San Antonio," "The Miraculous Apparition of the Christ Child," "The Sermon to the Fish," and "The 
Calming of the Seas" combined with "The Blessing of the Fish." The center rectangular scene depicts "The Miracle of the Mule" (Figure 8). Flanking the polychrome image of San Antonio are four additional scenes. The left plane contains two scenes: the upper, "San Antonio Preaching to the Masses," and the lower, "San Antonio Preaching to Three Monks." The right panels represent "The Miracle of the Dowry" spread over the two cells (Figure 9).

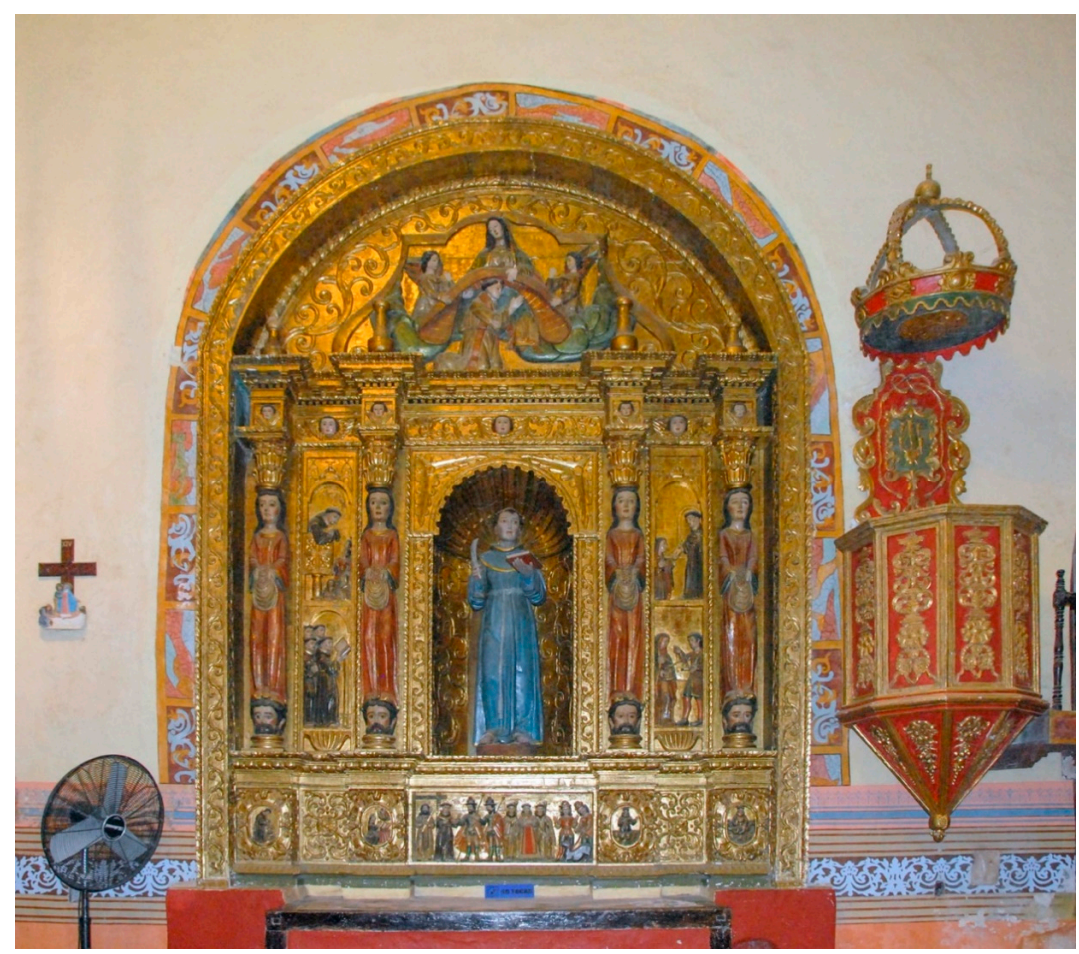

Figure 7. Pulpit and Retablo of San Antonio de Padua. Ex-convento of San Miguel de Arcángel, Mani, Yucatán, ca. eighteenth century. Photograph created by and used with Permission of Niccolò Brooker.

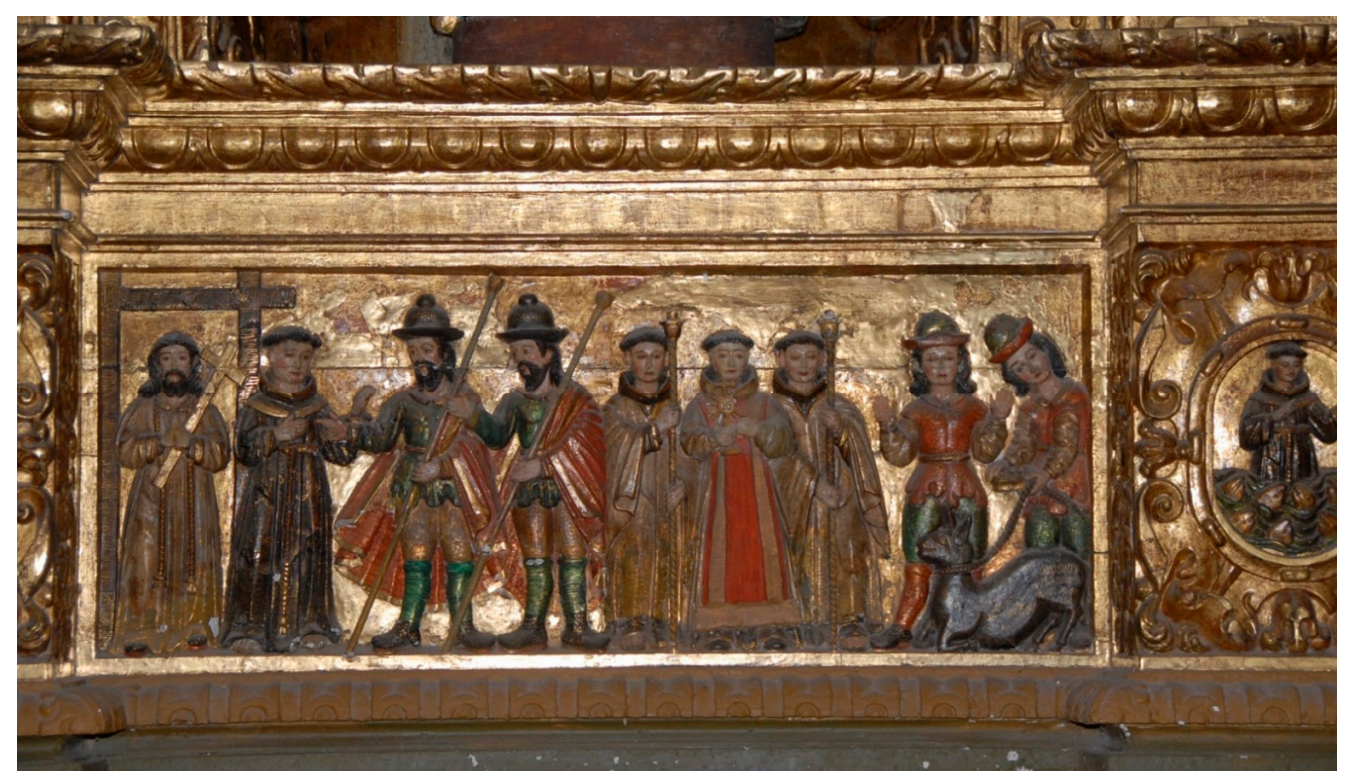

Figure 8. Detail, "Miracle of the Mule." Retablo of San Antonio de Padua. Photograph created by and used with Permission of Niccolò Brooker. 


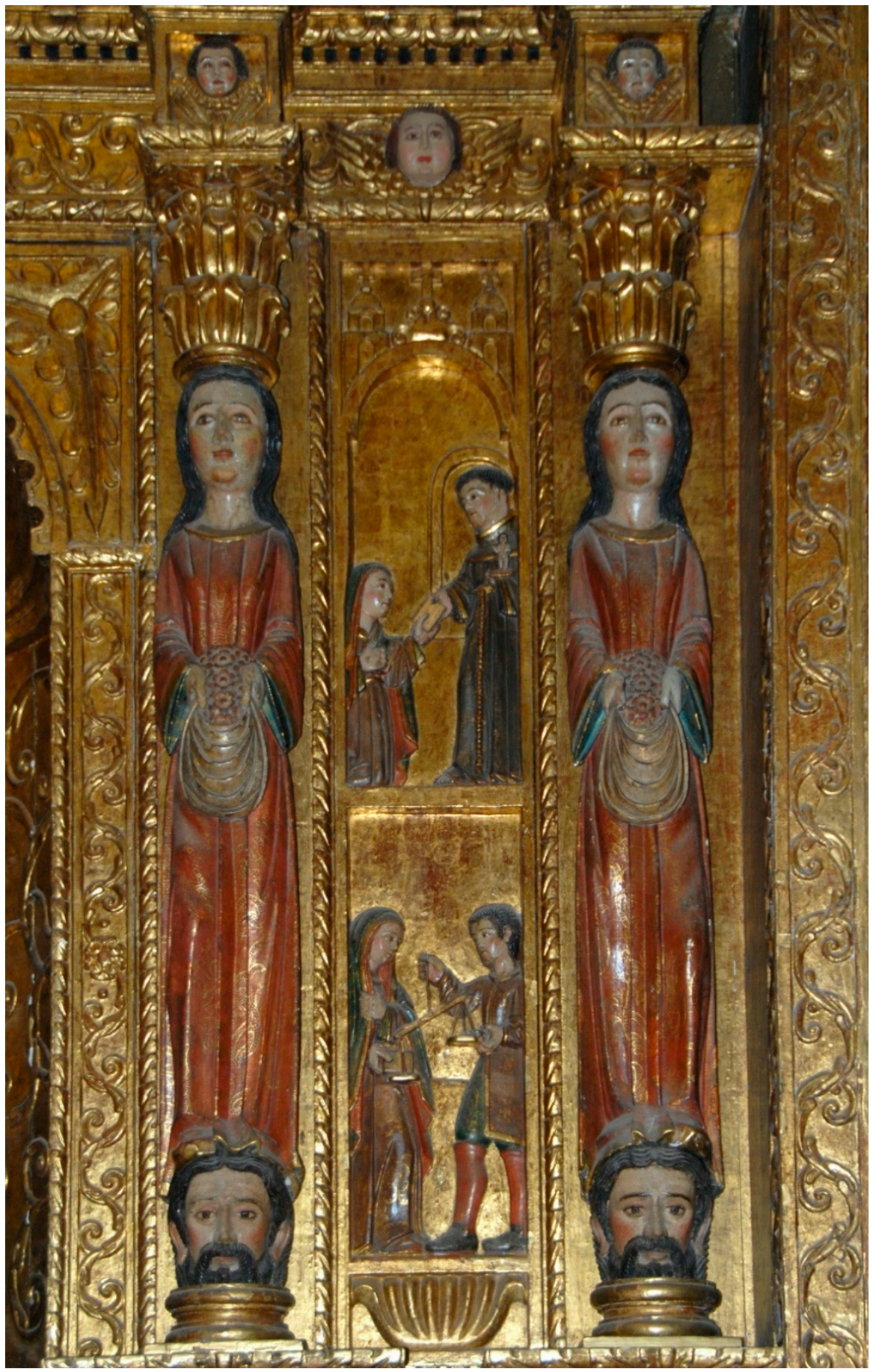

Figure 9. Detail, "Miracle of the Dowry": top scene "San Antonio Gives the Young Maiden the Parchment"; lower scene, "The Weighing of the Parchment." Retablo of San Antonio de Padua. Photograph created by and used with Permission of Niccolò Brooker.

Of the numerous scenes from the saint's life, the San Antonio artists from Mani made a significant contribution to the saint's oeuvre by depicting one of Antonio's posthumous miracles: the so-called "Miracle of the Dowry" (Barteet Forthcoming). According to Miguel Mestre's Vida y milagros del glorioso San Antonio de Padua of 1688, the miracle occurred at the convent of San Lorenzo in Naples (Mestre 1688). The legend tells of a young, beautiful poor woman who prays to San Antonio's image to free her from a life of servitude, which had resulted from her mother's inability to pay a sufficient dowry. The distraught maiden pleaded to Antonio to defend her honor, modesty, and chastity (Mestre 1688). 
Her prayers inspired the saint to intervene. His statue came to life and gave the woman a piece of paper, which read "You will give this woman that delivers this paper its weight in silver coins for her dowry. Promissory, Fray Antonio de Padua" (Mestre 1688). The animated statue instructs the devotee to take the paper to a local wealthy merchant. At first the merchant laughs at her as she recounts her instructions. Amused, he mockingly weighs the paper. To his astonishment, the paper instantly weighs as much as four-hundred silver coins. Recognizing the divine intervention, the merchant provides the young woman the money she requests in honor of San Antonio (Mestre 1688). The Mani retablo is among the only iconographic programs to include representations of the Dowry imagery. As an aside, a painted version of the work was created by the Ecuadorian painter Bernardo Rodríguez and Héctor Schenone notes that an anonymous image is in the Convent of San Francisco in Río de Janeiro, Brazil (Schenone 1992); aside from these images, I have only found a few references to the subject in ex-voto paintings of the late nineteenth century. Thus, the Mani artists made an important contribution to the to the saint's imagery. Further, the unique depiction of the story and the late seventeenth-century dissemination of the legend firmly places the retablo's creation at the turn to the eighteenth century.

Topping the retablo is a depiction of the Virgin Mary, flanked by angels, while she places a shroud over a saint; immediately in front of the saint is a bishop's mitre (Figure 10). Although I have identified the scene as "The Death and Investiture of San Antonio," this identification is problematic because the mitre is not an attribute of San Antonio (Barteet Forthcoming). Pascacio Guillén offers a different reading of the scene. She identifies the subject as "The Investiture of San Ildefonso" (Pascacio Guillén 2021). Saint Ildefonso was popular in Yucatán and the cathedral of Mérida is dedicated to his honor; investiture scenes were common in San Ildefonso's iconography. However, San Ildefonso has no direct connections to San Antonio and his iconography. At face value, both identifications are somewhat problematic: Antonio was never a bishop and Ildefonso was not among the precursors associated with Saint Francis, and his investiture is not invoked by the Franciscans. For now, I will leave the question of this identification unresolved, but will return to it in the conclusion of this essay.

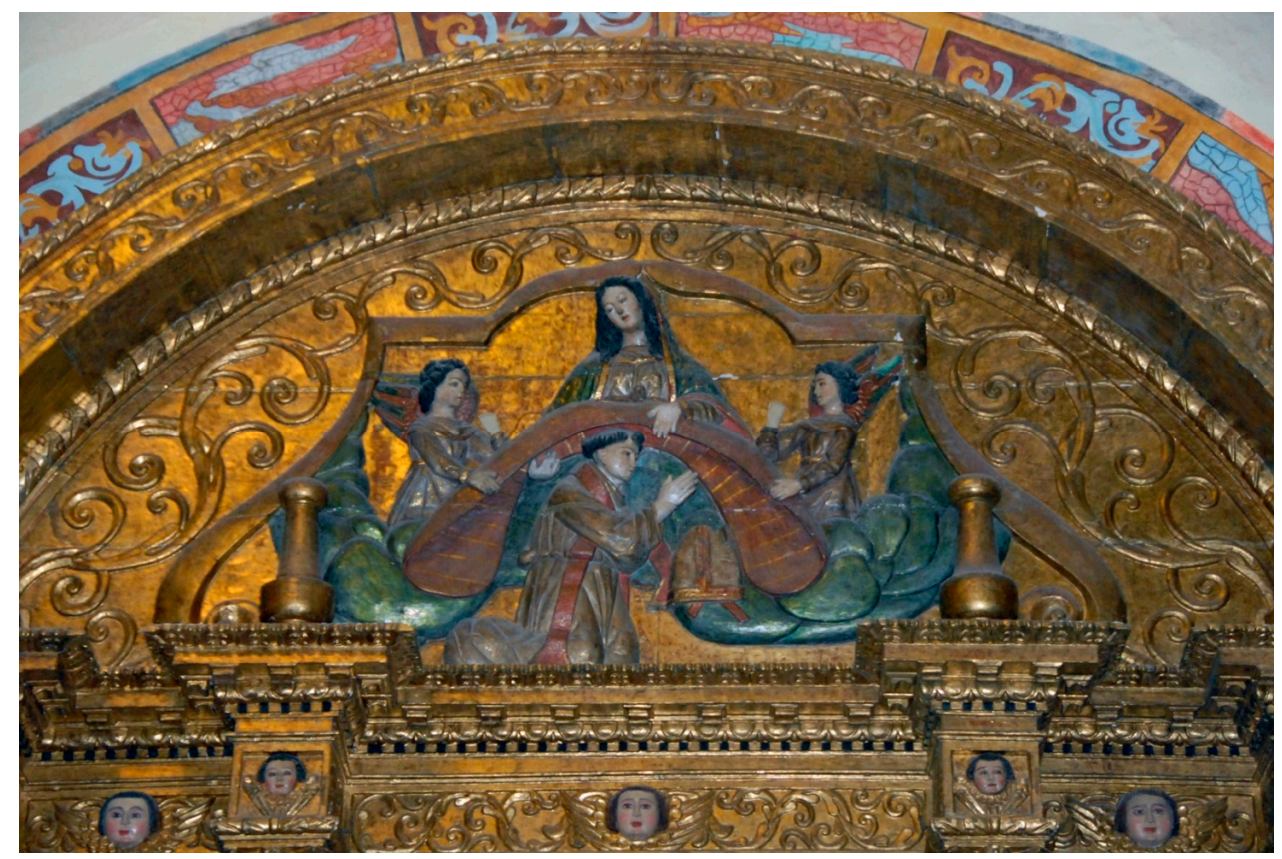

Figure 10. Detail, "Investiture Scene." Retablo of San Antonio de Padua. Photograph created by and used with Permission of Niccolò Brooker. 


\subsection{Retablo of Santa Teresita del Niño Jesús (Las Ánimas)}

At Teabo is the Retablo of Santa Teresita del Niño Jesús (see Figure 3). It is worth mentioning that Santa Teresita is not a colonial saint. Rather, she lived in late nineteenth century. Santa Teresita or Thérèse of Lisieux (1873-1897) was canonized in 1925. She is among the most popular twentieth-century saints who has shrines throughout Europe and the Americas. Indeed, her relics were taken on a world tour starting in 1994 and appeared in Yucatán in 2001. Thus like its precursor now at Mani, the retablo's name is derived from the central modern sculpture and not the larger iconographic program. Nevertheless, the Santa Teresita retablo has a rich iconographical program like the La Soledad altarpiece. Recent restorations at the church revealed a wonderful series of murals in its sacristy depicting the Apostles, the Doctors of the Church, and other religious figures. The range of color in the sacristy frescoes are mirrored in the Santa Teresita retablo. The altarpiece echoes La Soledad's design in virtually every detail: predella scenes, caryatids, symmetrical niches, imposts scenes, and a large tympanum. The significant difference between the two is connected to the repainting of Santa Teresita's gold leaf background. Nevertheless, to begin with the predella, again there are seven scenes represented, six of which are displayed in the roundel format. The seventh scene is rectangular like the San Antonio retablo. The fiery-red scene of "Purgatory" depicts the souls (ánimas) of the deceased awaiting Christ's judgment. Rather than seeing Christ's ultimate judgement, the scene depicts the Virgin of Sorrows to the left and St. Joseph holding the Christ Child to the right. All around the holy figures are the flames of Hell that engulf twelve figures (the condemned), which include a bishop and several friars. Flanking the image of purgatory are references to the Arma Christi: the "Flagellation" to the left and the "Ecce Homo," with Christ situated beside the Cross and the pillar to the right. Beyond them are large medallions, each of which contain an angel holding instruments from the Passion: the left holds the Cross and a chalice, and the right holds the reeds, the whip, and the pillar. The extreme left and right scenes of the predella mimic the La Soledad altarpiece: "The Agony in the Garden" and the "Carrying of the Cross,", respectively.

Again, caryatids standing upon bearded male heads, hold satchels of flowers. Their heads are topped by double capitals that support impost scenes. These scenes also represent the Arma Christi (from left to right): "The Nails, the Pincers, and the Hammer," "The Crown of Thorns and the Box of Myrrh," "The Seamless Tunic and the Thirty Pieces of Silver for Judas," and "The Knife, the Sponge, the Lance, and the Lantern." The upper pediment depicts the Cross surrounded by the Virgin Mary to the left, St. John the Evangelist to the right, and Mary Magdalene at the center, kneeling and embracing the Cross (Figure 11).

Here, again there are a somewhat unsettling iconographical combinations insomuch as the combination of Purgatory with the Passion are not frequently conflated with one another. Although several compositional design features within the various scenes repeat throughout-for example, the rounded faces and sun bust halos in both representations of the Virgin Mary, as well as the stones portrayed at the foot of the cross and those in the scene of "Christ Carrying Cross" - a disconnect exists about the larger narrative. This could simply be a narrative choice connected to the now lost commission for this retablo, or it could allude the potential of the altarpiece being a form of pastiche in that various fragments of altarpieces were combined to create the Santa Teresita. Such issues are further compounded aesthetically by the three smaller polychrome sculptures that Pascacio Guillén has dated from the seventeenth to the twentieth centuries (Pascacio Guillén 2021). The central image depicts Santa Teresita del Niño who is flanked to the right by "San Miguel de Arcángel slaying the Devil," and "The Risen Christ" in the opposite niche (Figure 12). The size of the works suggests the figures of Miguel and Christ are likely seventeenth-century devotional works (Pascacio Guillén 2021). At its core, the Santa Teresita retablo is dedicated to the Arma Christi that has been expanded to include a scene of Purgatory. 


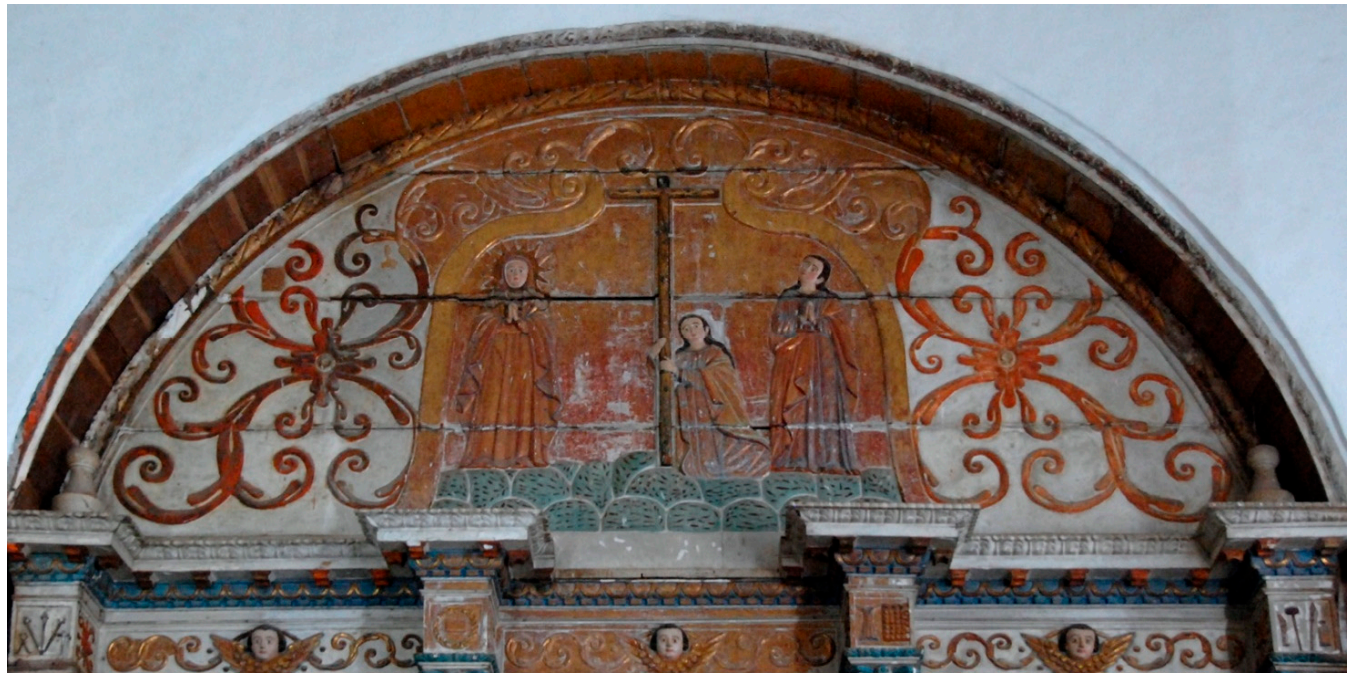

Figure 11. Detail, "The Virgin Mary, Mary Magdalene, and Saint John the Evangelist at the Cross." Retablo of Santa Teresita del Niño Jesús. Photograph created by and used with Permission of Niccolò Brooker.

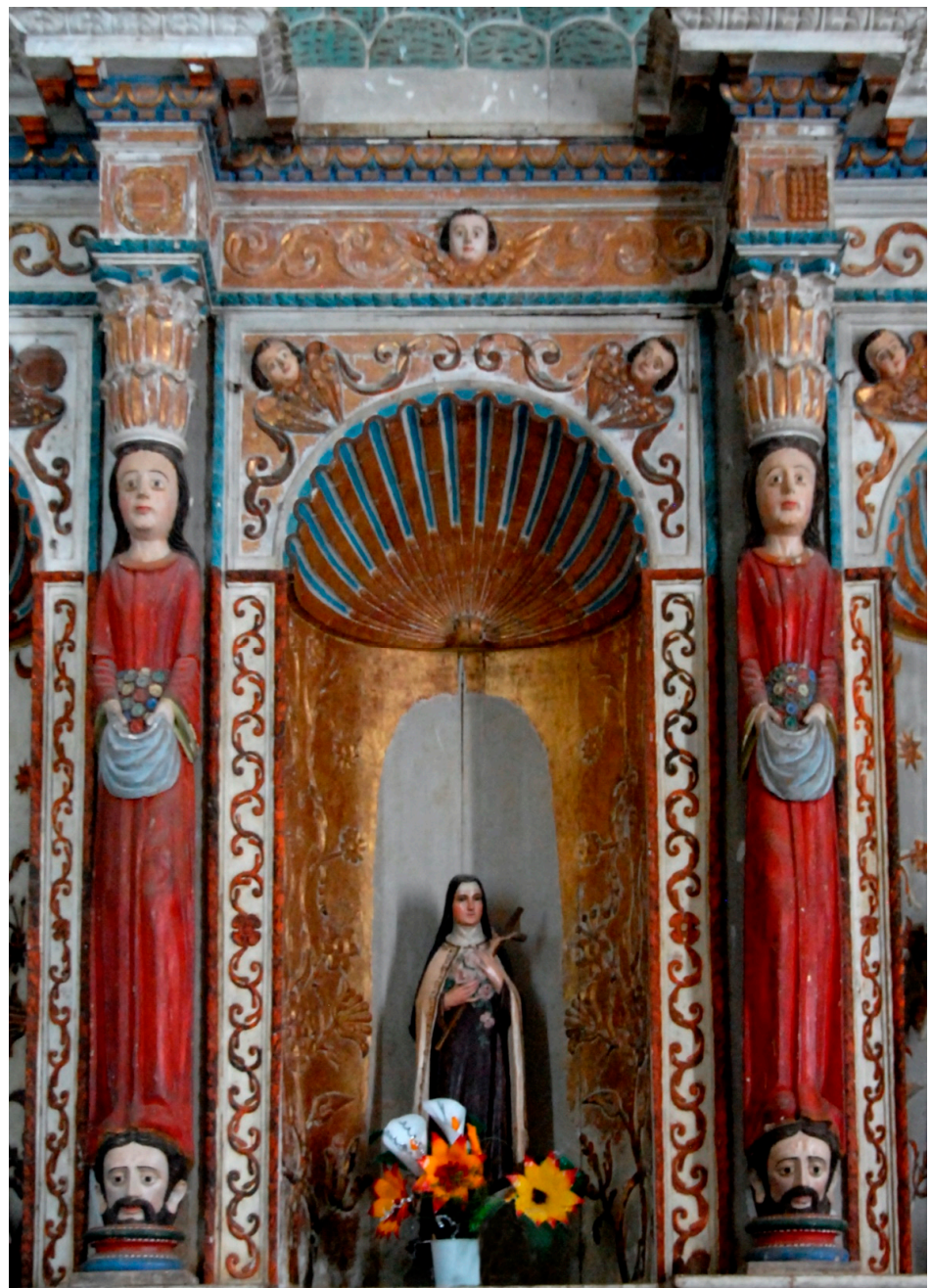

Figure 12. Detail, "Santa Teresita del Niño Jesús." Retablo of Santa Teresita del Niño Jesús. Photograph created by and used with Permission of Niccolò Brooker. 


\section{The Discussion: Artists, Caryatids, Dating, Locations}

The formal and iconographical discussion of the three altarpieces confirms the retablos' similarities but also reveals differences. Here, I will explore these traits by discussing their possible artists and the symbolism of the caryatids. These considerations lead into issues of dating and the location of the retablos.

\subsection{Artists}

At the present we unfortunately have not recovered many names of colonial Yucatecan artists. However, we know that Maya, creoles, Spaniards, and Africans were trained in the visual arts (Farriss 1984). Since the 1540s Maya males learned Spanish visual models through Franciscan convent schools like the one established in Mani. They were taught theology, language, and the visual arts. In his Historia de Yucatán: Devocionario de Ntra. Sra. de Izmal y Conquista Espiritual (1633), Lizana praises the work of Fray Julián de Cuartas, who Lizana credits with training a generation of Maya artists in the Spanish traditions of painting, gilding, and carving, skills needed to make retablos and the other visual objects to decorate Yucatán's churches (Lizana 1983). Confirming Lizana's assertions are the seventeenth-century writings of Pedro Sánchez de Aguilar. Aguilar noted that every Maya town had numerous artisans, including herreros, zapateros, carpinteros, silleros, sastres, pintores, entalladores, canteros, and albañiles (Sánchez de Aguilar 1639). Further validation is provided by historian Marta Hunt. In examining the 1795 census for Mérida, Hunt found that 1551 artisans were recorded for a general population of well over 5000 people (Hunt 1974). Among the few names Hunt recovered was the Maya painter Francisco de Pech who lived in a prominent neighborhood in seventeenth-century Mérida (Hunt 1974). Others included Bernardino Canul who carved a nineteenth-century retablo for the cathedral in Mérida. However, Pech and Canul are not the norm.

Nevertheless, we know that these and other artists were active. In the seventeenth century Fray Diego López Cogolludo confirms the existence of numerous retablos in Mérida's churches and convents. Among those he discusses are the five altarpieces from the Convent of San Francisco, the seat of the Franciscan order in Yucatán. Cogolludo documents that five retablos were dispersed along the convent's north and south walls; the north wall's retablos were dedicated to the Crucifixion, San Diego of Alcalá, San Antonio of Padua, and along the south wall were altarpieces to the Crucifixion and Purgatory, and to San Louis IX King of France (Cogolludo 1688). ${ }^{4}$ Aside from retablos, we also know that numerous other visual objects were produced for Mérida's residents. Historian Nancy Farriss has noted many instances from the seventeenth and eighteenth centuries where private devotional images are mentioned as part of estates in notarial records, and I would add types of three-dimensional sculptures similar to those found on the that occupy the niches in the Santa Teresita retablo (Farriss 1984).

Many of these sculptural and painting traditions would correspond to those practices found in pre-contact Maya traditions. Farriss has noted even as late as the eighteenth and nineteenth centuries there was a highly skilled group of Maya masons from Oxkutzcab, a community in the province of Mani (Farriss 1984). Farriss has speculated that the Maya dominance in stonework is a biproduct of Yucatán's long building history that predates the Spanish's arrival. As she notes, the Maya relied upon autarky production models, where forms of technical and artistic knowledge were passed from generation to generation, a practice that existed in pre-contact times (Farriss 1984). For centuries Yucatecan peoples have passed knowledge down about agriculture, writing, painting, building and sculpting. On some level these traditions mirrored the Spanish generational focus on practices of the visual and buildings arts.

4 Saint Diego de Alcalá (or Saint Didacus). He was among the first Franciscans to assist in the acculturation of the Canary Islands. Saint Louis is the co-patron of the Third Order of Saint Francis. He is associated with Franciscans because of his charity to the poor. 


\subsection{Caryatids}

As art historian Elisa Vargaslugo has noted, in Yucatán caryatids are a favored sculptural device employed in religious works, as exemplified by the sixteenth-century wooden pulpit for the church at Motul, and the Mani and Teabo altarpieces (Vargaslugo 1988). The caryatids are undoubtedly European in origin and they appear frequently in Spanish Renaissance art including Andres de Vandelvira's, "Puerta de la Sacristia (Úbeda)", 1540; Esteban Jamete's (Etienne Jamet), "Sacristía de la Sacra Capilla del Salvador (Úbeda," ca. 1541-44; Diego de Tiedra's, "Capilla de los Muñoz (Cuenca)," 1537; Alonso de Covarrubias', "Hospital de Santa Cruz (Toledo)," 1514; and Martín de Mezquita's, entry façade for the Catedral de Nuestra Señora de la Huerta (Tarazona), 1578 (Figure 13) along with print sources like Fray Giovanni Giocondo's (1511) (Figure 14) text dedicated to Vitruvius. Take for example, Mezquita's and Giocondo's caryatids. Each has an implied raised knee and stand upon pedestals. Whereas the attire of Giocondo's caryatids is abruptly columnar, by contrast the Tarazona figures are much more active and realistic. Aside from having more distinctively feminine features and implied bent knee movement, one of the cathedral's terms holds flowers at her waist. On the Tarazona cathedral, as Jesús Criado Mainar has documented the six caryatids of the portal, when combined with the image of Charity in the archivolts, create the seven virtues (Mainar 2017). The virtues are paired with the Four Doctors of the Church and Saints Peter and Paul, along with the region's patron saints: San Prudencio and San Gaudioso. The virtues are divided into two categories. The theological virtues - faith, hope, and charity — that are frequently associated with the laity's devotional practices in their faith in God, and charity to one another. The cardinal virtues are justice, prudence, fortitude, and temperance. These virtues are frequently associated with the clergy and monastic traditions as they maintained patience in their actions and judgment along with the temperance and fortitude to abstain from sin. Indeed, there are numerous examples of the virtues depicted on effigies and tombs throughout Europe, including the Sepulture of Cardinal Tavera (by Alonso Berrugute) and Sepulture of Cardinal Cisneros (Bartolomé Ordóñez). The more famous images though are in Italy, including those found throughout the Vatican complex for tombs or in Raphael's Stanza di Eliodoro (ca. 1512) in the papal palace. These images, like those on the portal at Tarazona have important iconographical functions. At Tarazona, when the caryatid-virtues are combined with the religious figures on the portal, the social and religious mandates of the church are espoused: the salvation of man through Christ and adherence to the charitable virtues. Mazquita's façade is far from unique with its caryatids identifying as virtues. Indeed, in all the works listed above, caryatids are iconographical references to the virtues.

The Yucatecan caryatids are undoubtedly connected to these Spanish practices, and indeed, there were friars operating in Yucatán from all over Spain, including Fray Melchor de Tarazona in the late sixteenth century who resided in the convento grande in Mérida before traveling to Yucatán's south-western coast in the 1570s. Whether directly connected to the influence of Fray Tarazona's contacts from his hometown or simply based on the numerous Spanish models, the Yucatecan caryatids are most likely iconographical references to the virtues.

In the three Yucatecan retablos, the virtues have been reduced to the four cardinal virtues. The cardinal virtues are frequently associated with the monastic orders as they relate to the processes of spiritual training and devotion. Such imagery would be appropriate for the retablos that adorned Franciscan monasteries, particularly La Soledad that has iconography evoking meditation on Christ's suffering brought about by man's deceit and betrayal. Unlike the virtues present at Tarazona cathedral that once were identified by icons that adorned their pedestals, the four virtues on the Yucatecan retablos are superficially rendered, thus suggesting that they were mnemonic devices for a literate Franciscan fraternity. Further, if combined with the three angelic figures of the La Soledad's pediment, the seven virtues are rendered. The three pediment figures would represent the theological virtues of faith, hope, and charity that are correlate to Christ's Crucifixion: man's faith in God through the incarnate Christ, hope through the desire for eternal salvation in the 
Kingdom of Heaven; and charity as exemplified by Christ's willingness to be crucified for man's eternal life.

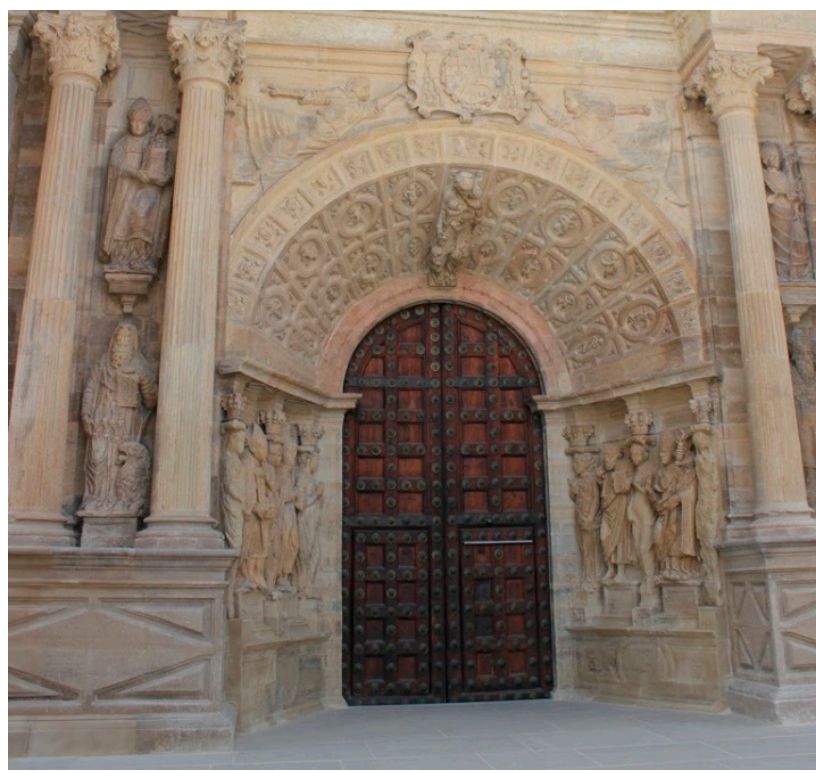

Figure 13. Martín de Mezquita Entry Portal, Catedral de Nuestra Señora de la Huerta, Tarazona, Spain, 1578. Image in public domain.

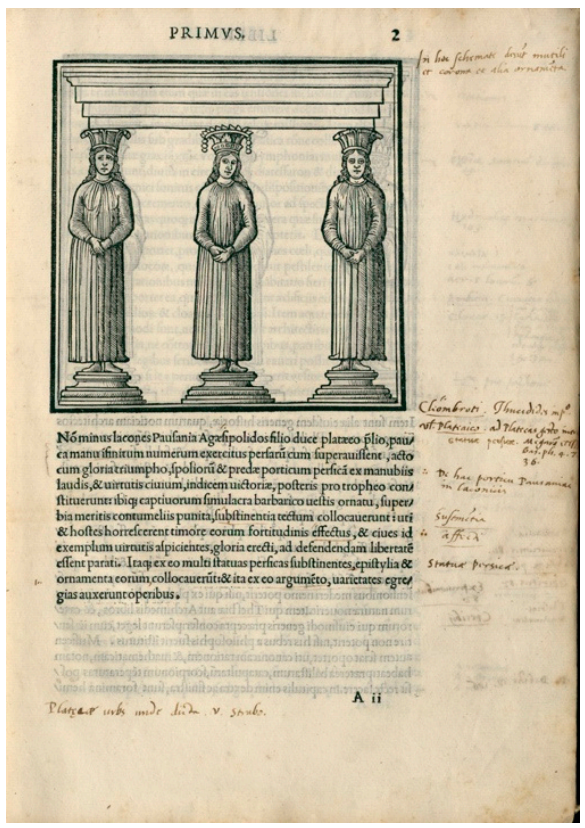

Figure 14. Giovanni Giocondo, M. Vitruvius per Jocundum solito castigator factus cum figuris et tabula, f. 2. Vencia: G. da.Tridentio, 1511. Image in public domain.

To further reinforce the idea of contemplation on the cardinal virtues and Christ's sacrifice, the caryatids all carry satchels filled with multicolored pansies. In Christian traditions pansies are symbols for the remembrance for mediation. Although similar in appearance to certain types of anemone-flowers associated with the Virgin's sorrows at Christ's death-pansies are appropriate flowers to adorn Franciscan decorations, particularly ones dedicated to the Passion and the Arma Christi, which are most often represented in books of hours and other devotional imagery. The Arma Christi acted as mnemonic devices that solicited the viewer to mediate upon the various moments in the Passion of 
Christ and that lead to his eventual triumph over sin and death. In other words, Santa Teresita and more specifically La Soledad, were designed for spiritual contemplation like those practices carried out in cloistered monastic communities, and not for congregations of parish churches like those at Mani and Teabo. Recognizing this function, here must begin to consider the issues of location.

Before moving on to their locations and dating, there are additional points that should be mentioned about the Yucatecan caryatids. There is a significant difference between the Iberian caryatids and those of the retablos under study: the Yucatecan caryatids stand upon bearded heads. In Yucatán there exists a complex visual tradition of showing conquestspiritual or political - through the visual format of standing conquerors over disembodied heads. Indeed, there are several examples in the Palacio Canton (Museo Regional de Yucatán, Mérida) that show powerful pre-contact Maya rulers standing upon defeated enemies, whether bound, prone, or beheaded. In the colonial era, the use of term-style figures originated in Yucatán's Hispanic visual culture with the façade of the Casa de Montejo (Figure 15). On the building, armed halberdiers stand upon conquered heads. Although they are sculpted in the round, the halberdiers are herms (male caryatids) and not acroteria like their flanking wild men. Like the armed soldiers on the Montejo façade, the caryatids' compositions are rooted in Spanish traditions of Santiago Matamoros, an iconographical composition meant to evoke the conquest of Christianity over vanquished heretical enemies. ${ }^{5}$ The caryatids continue this tradition as the slim vertical, female figures effortlessly stand upon conquered enemies. That this composition would appear on religious structures is likely a direct correlation to the challenges the Franciscans faced in the evangelizing and acculturating of the Maya. There exist numerous instances of Maya resistance and resiliency, including the 1562 auto-da-fé in Mani. During the spectacle, Fray Diego Landa infamously burned thousands of so-called heretical idols and texts. Prior to Landa's inquisition on 29 September 1548 two Franciscan Friars, Luís de Villalpando and Toribio de Benavente, were almost killed at the Xiu town of Oxkutzcab, located a few kilometers away from Mani. Lizana tells us that it was only through the friars' devotion and prayers that they were saved (Lizana 1983). In light of such events, it is not expected that such conquest imagery would be found on the retablos.

However, it is important not to gloss over this composition for other reasons as well. For one, Yucatán's conquest was a bloody affair, as the Maya outwitted the Spanish for well over a decade and it was only through Santiago's divine intervention that the Spanish were not completely decimated in 1535 (Oviedo y Valdez 1851). In part, the Montejo façade commemorates the saint's intervention, but the context is more complicated (Barteet 2019). Although it is generally assumed that all the Spanish conquistadors were male, they were not. Andrea del Castillo, the wife of the governor's son, identified herself as a conquistadora and received a royal stipend for her services in Yucatán's colonization (Castillo AGN 1572). Castillo's influence on early Mérida is significant as she was actively involved in the establishment of the city and supported the preservation of the Casa de Montejo (Arrigunaga Peón 1965; Barteet 2019). Thereby, Castillo offers a literal precedent for the creation of conquering female imagery in Yucatán. Although they likely relate to the Christian conquest of the peninsula as well as monastic mediation, the caryatid compositional framing devices cannot be taken out of the rich visual culture of Yucatán before, during, and after the Spanish conquest. 


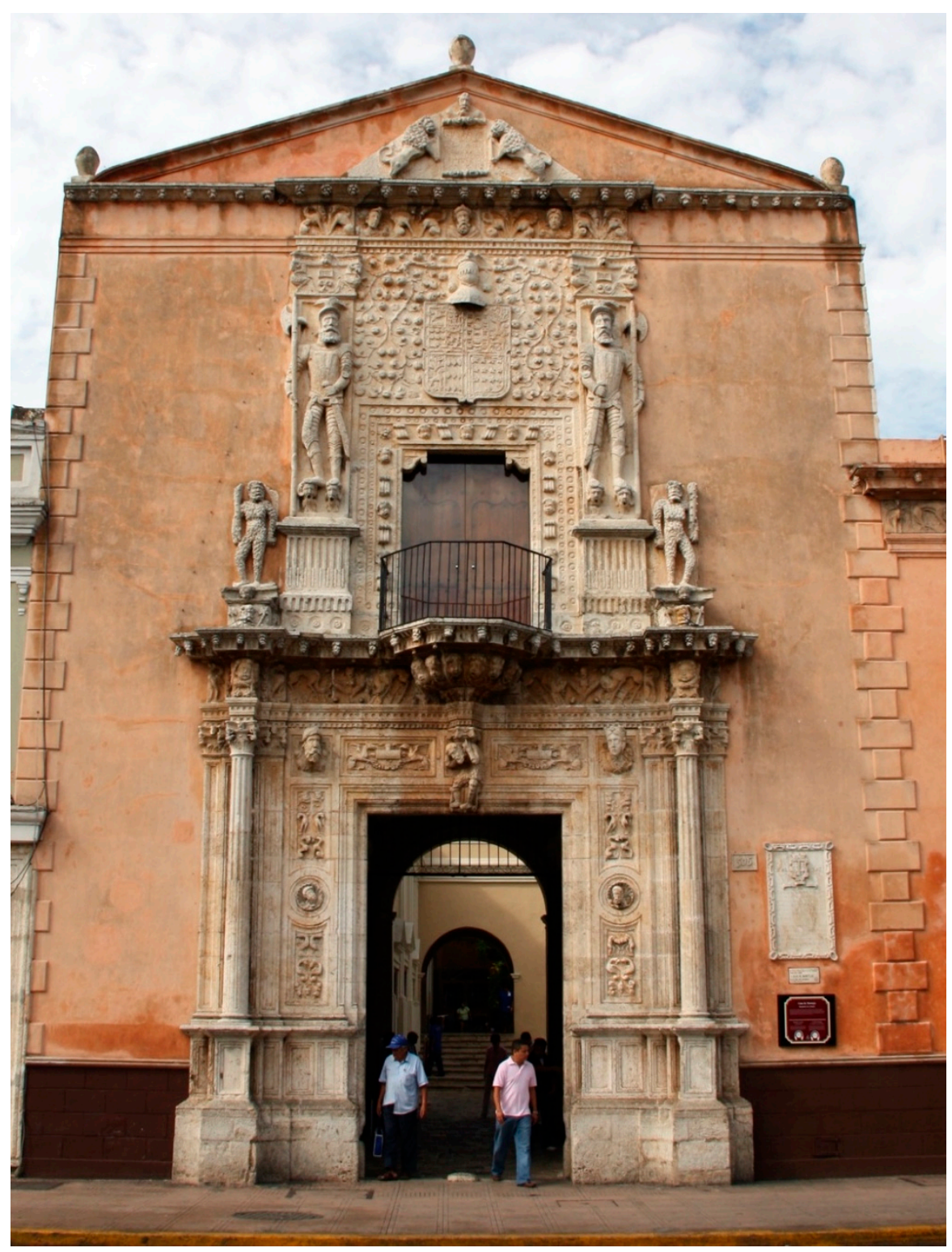

Figure 15. Façade of the Casa de Montejo, Mérida, Yucatán, ca. 1542-49. Photograph created by author.

\subsection{Dating}

To address issues of dating, the three altarpieces' dentils may offer some clues. Of the three, the La Soledad retablo is visually more articulated and crafted in its formal architectural elements. This articulation could suggest that the work was made by a more skilled sculptor and it could assist in dating the object (Figures 16 and 17). The sensibility and iconography of the retablo easily conforms to sixteenth-century Plateresque practices. The techniques were materialized in their full grandeur on Mérida's plaza mayor through the Montejo façade. The palace's façade operates on many levels, ranging from the selfpromotion of its patron and civic values to religious overtures and the Montejo family's supposed divine mission to settle and evangelize Yucatán (Barteet 2019). To build their palace, the Montejos forced the peoples of the Mani province into servitude (Bienvenida AHN 1548). Further, the friars in turn forced the Maya of the Mani province to build the monastery at Mani in seven short months. Ironically, these laborers likely created an important sculptural studio that would go on to carve façades and retablos throughout Mérida and its hinterlands. Indeed, the studio easily could have been populated by the highly skilled stoneworkers and stonecutters of Oxkutzcab that Farriss has discussed, and 
the same community that sought to kill the two friars. Nevertheless, the articulation of forms on the La Soledad retablo is quite possibly connected to the Mérida studio that originally carved the palace's façade.

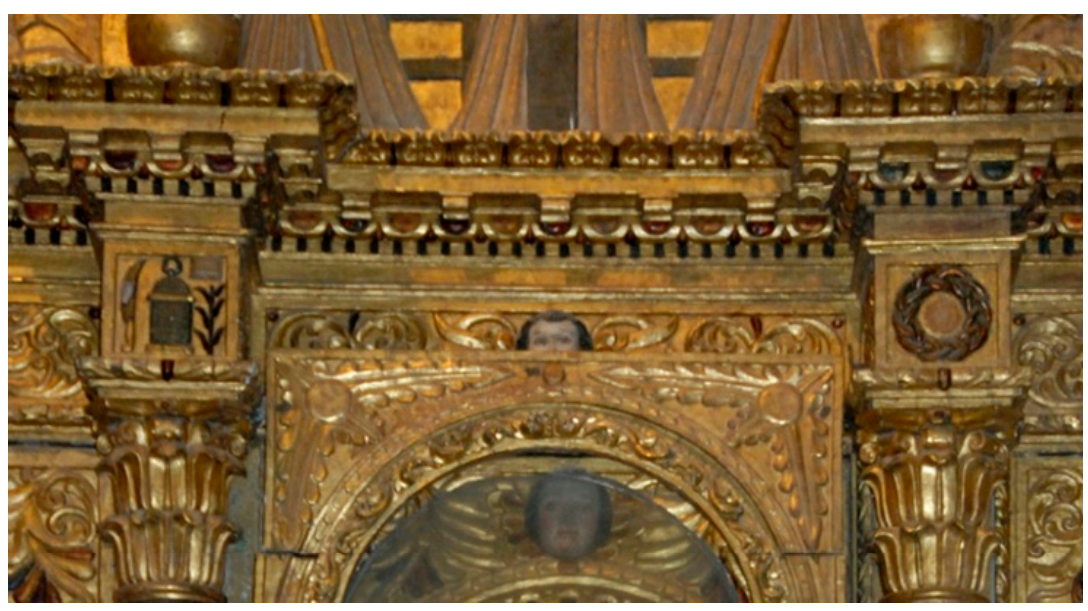

Figure 16. Detail, Entablature and Dentil, Retablo of Nuestra Señora de la Soledad. Photograph created by and used with Permission of Niccolò Brooker.

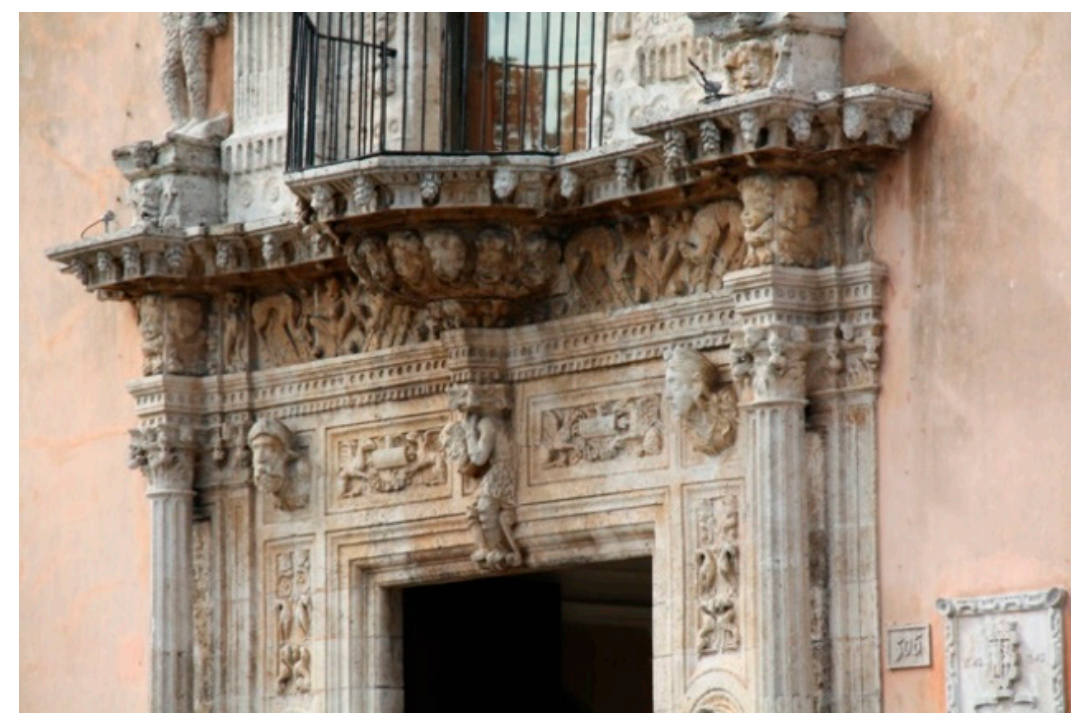

Figure 17. Detail, Lower Entablature and Dentil, Casa de Montejo. Photograph created by author.

Additionally, the retablo's surface patterning is steeped in sixteenth-century Plateresque traditions unlike the sculptural applique in the two other altars. As noted, the contrast of fantastical creatures surrounded by vegetation to discernable architectural features and clearly defined persons reinforces the authority of Christianity as manifested through man's rational thought and (Álvarez 2001; Barteet 2019). Frequently, there exists a contrast between the clarity of the important religious features: inscriptions, saints, or icons objects like the Arma Christi to the dense foliage and grotesques that occupy the opaque voids between the discernable objects.

Recognizing these ideological meanings applied to the Plateresque offers some reasoning for its choice in early Yucatán, as the Spanish were attempting to establish their presence there. In examining the retablos, La Soledad is quintessentially Plateresque as its Renaissance proportions and articulated architectural features are overlaid with dense surface patterning that is a hallmark of the idiom. The surface patterning is only broken by the easily perceptible symbols of the Arma Christi and architectural features. Such sensibility to the style suggests to me that the work was produced by artists intimately 
familiar with the style. Here, it should not be forgotten that Convent of San Francisco was founded in Mérida in 1547 and soon thereafter the process begun to convert the former Maya temple mound into a traditional cloistered Franciscan monastery. Indeed, during Fray Diego de Landa's lifetime (d. 1579), Landa noted the Franciscans has already built a monastery and "una buena yglesia [sic] que llamamos la Madre de Dios" (Landa 1566). Presumably, this fine monastery was decorated with some of the elegant retablos that Cogolludo documented, including a retablo along its north walls dedicated to the Crucifixion. Considering, the strong Plateresque features on the La Soledad altarpiece, the work must have been made by the generational workshop of the Montejos' palace. The retablo's Plateresque narrative content, its pinpoint focus on the Arma Christi, the reference to the cardinal and theological virtues, and to spiritual meditation, strongly suggest the altarpiece was made for the Franciscan monastery and not for the lay population. It was not until the seventeenth century that convent was expanded to include a parish. ${ }^{6}$ Thus, the Convento Grande of San Francisco would have been such a place for the cloistered monks to engage in spiritual mediation. In this way the convent differed from those outside of Mérida that were designed to attend to the local population's spiritual needs along with the friars. It seems then, that the dense iconographical program of the La Soledad altarpiece was made for a cloistered community of monks and not the local laity. Recognizing this iconographical specificity would lend to the theory of dating the retablo to the last decades of the sixteenth century when the friars at the Convent of San Francisco engage in cloistered spiritual mediation. Therefore, it seems the retablo was later moved to Mani, a point I will return to the following section.

Nevertheless, with some semblance of a timeframe for the La Soledad retablo and the San Antonio altar, some discussion should be briefly given to the Santa Teresita retablo. Unlike the other two retablos, dating the Teabo altarpiece is a bit challenging because of its overpainting and sculptural additions. However, the approach to Renaissance style is more appliqué than based on Plateresque tenets. Like the San Antonio retablo, the Santa Teresita altarpiece adopts the practice of emulating forms that would have been present on an important retablo from the convento grande Franciscan monastery in Mérida. The retablo likely was commissioned sometime after the construction of the new church. Teabo was begun in the last decade of the seventeenth century. Combined, the subjects would facilitate the dissemination of the theological message to a larger lay population. Considering these facts, the work seems to date to the eighteenth century and adopts a pictorial format of a principal retablo from the Convent of San Francisco.

\subsection{Locations}

In the previous section, allusions to locations were being hinted at. To summarize, I have suggested that the retablos to La Soledad and Santa Teresita were crafted for the former convents in Mérida and Teabo, respectively. Here, I will delve deeper into my discussion of La Soledad while referring to the altarpiece to San Antonio. In approaching issues of the retablos' locations, it should be remembered that the La Soledad and San Antonio retablos are two of the seven major retablos in the nave of San Miguel de Arcángel (Figure 18). By all accounts this is a significant number of works that far outnumbers the majority of other churches throughout Yucatán. Indeed, the convento grande in Mérida only had seven retablos along its main chapel's walls. Additionally, all but three of the retablos are in recessed wall niches: the large, apsidal San Miguel retablo and two retables along the north wall, La Soledad, and a Churrigueresque-style altar (Figure 19). As Pascacio Guillén has documented, between 1904 to 1914 Archbishop Martín Tritschler y Córdova initiated a revitalization program that was designed to repair and rebuild many of the churches of Yucatán that were destroyed during the violent Yucatecan Guerra de Castas (Caste Wars) of the mid-to-late nineteenth century (Pascacio Guillén 2021; Alexander 2004). In

6 It was not until the seventeenth century that one of the convent's chapels (San Cristóbal) was expanded to operate as a parish church (Cogolludo 1688). 
many respects, Archbishop Tritschler y Córdova was responding to what had been almost a century of destruction to religious structures, which began with the suppression of religious orders in the 1820s. Indeed, the nineteenth-century American explorer John Lloyd Stephens recounted the story of the sacking of the Convent of San Francisco on 30 May 1820 (Stephens 1848). Stephens' account of its sacking is based on information he gained while visiting Yucatán some twenty years later. Stephens writes that the monk's tombs were desecrated, and "The altars were thrown down" to make room for new military barracks (Stephens 1848). The destruction at the monastery and at other ex-conventos in Yucatán was extensive, and Archbishop Tritschler y Córdova was attempting on some level to reconcile a violent moment in Yucatán's history. Indeed, the archbishop's campaign was significant. At the end the nineteenth century Yucatán had ninety-seven operating churches or parishes. By 1910 that number had almost doubled under Tritschler y Córdova to 179 churches being either restored and built under his influence (Rubio Mañe 1941; Menéndez Rodríguez 1995). To complete his program, Archbishop Tritschler y Córdova enlisted many of the wealthy individuals and families in Yucatán (Rubio Mañe 1941). It is during this time of renovation that the salvageable retablos from the Convent of San Francisco and other churches found new homes. It seems both Mani and Teabo were relatively untouched by the violent uprisings. The complexes received limited renovations as opposed to other complexes in the Mani Province (Menéndez Rodríguez 1995). Further, that Mani had a rich visual tradition of retablo production and the physical space for expansion, Mani must have been viewed as a suitable location that was further enhanced by the strong similarities between the La Soledad and San Antonio retablos.

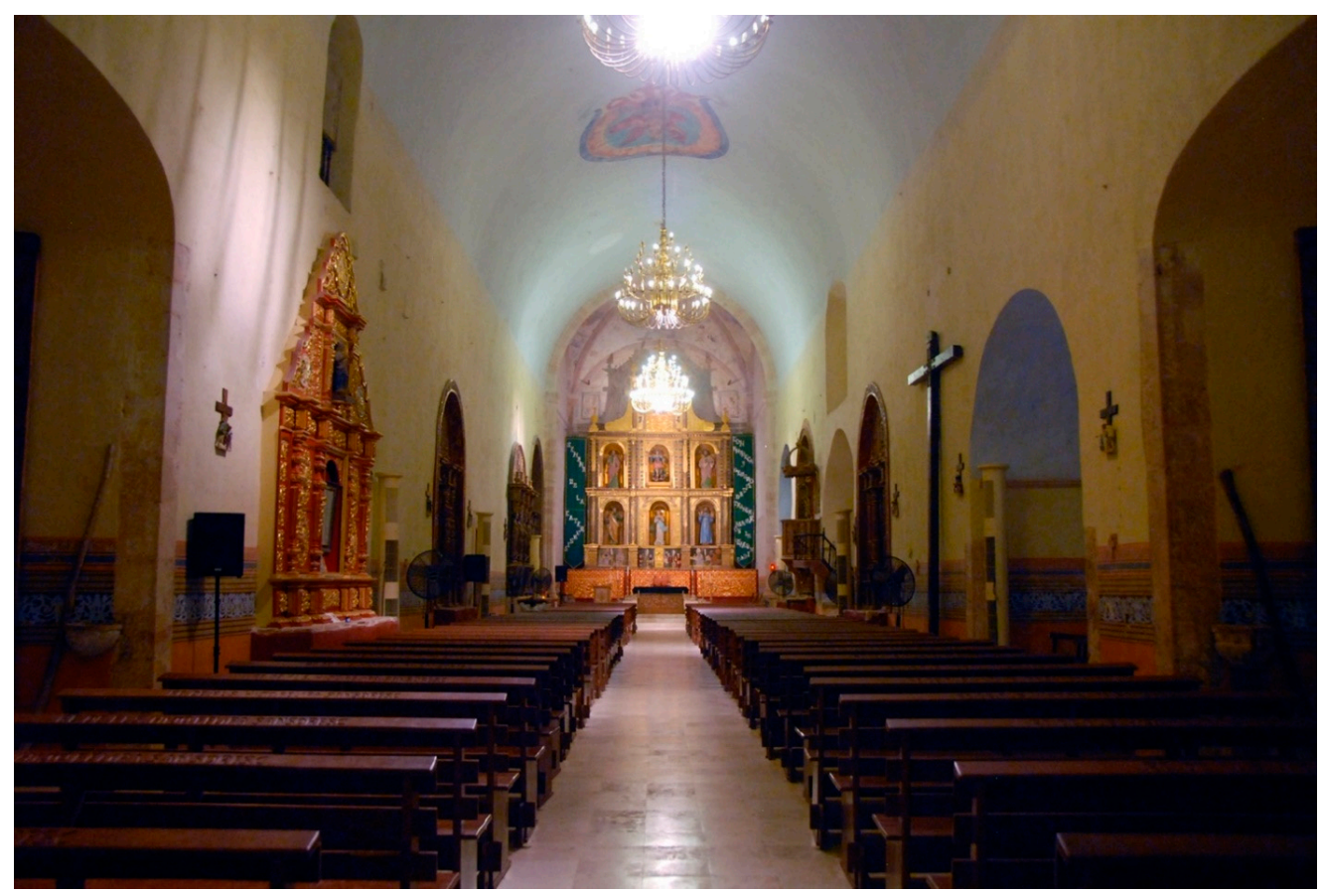

Figure 18. Nave, Showing All Seven Retablos of the Ex-convento of San Miguel de Arcángel, Mani. Photograph created by and used with Permission of Niccolò Brooker. 


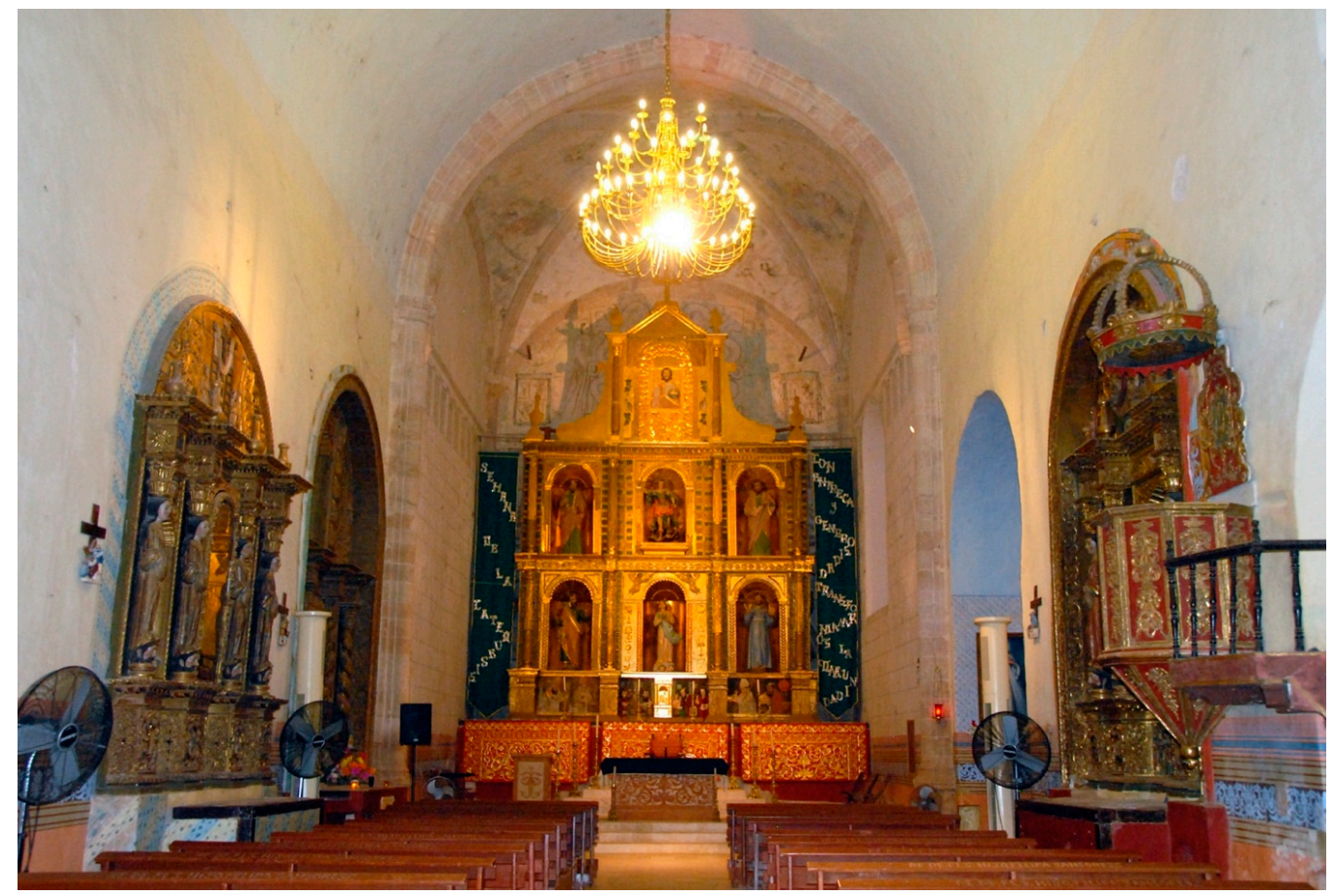

Figure 19. Nave, Showing the relationship between the Retablo of Nuestra Señora de la Soledad (left) and the Retablo of San Antonio de Padua with Pulpit (right). Ex-convento of San Miguel de Arcángel, Mani. Photograph created by and used with Permission of Niccolò Brooker.

\section{Conclusions}

Exploring recent research on the three retablos is providing a much-needed reevaluation of their histories. However, much is still uncertain about these works. To close, I want to return to the San Antonio retablo as a means to indicate the challenges still facing the field of Yucatecan retablos. As noted, capping the altarpiece is a rather opaque scene (see Figure 10). The section is composed of two angels that assist the Virgin Mary in placing a stole or a cloak of investiture upon a male figure, directly in front of whom is a bishop's miter. The work is problematic: Antonio was never a bishop and Ildefonso was not directly associated with the Franciscan order and his investiture is not connected with San Antonio. To mediate these irregularities, a closer examination of the restoration efforts of Archbishop Martín Tritschler y Córdova should be taken into account. For example, during this time of high mobility for artworks following a period of extreme cultural and physical rupture, we must consider that many altars may not be in situ and that they could easily have been altered, abridged, or augmented. We must consider such things as the significance of minor inconsistencies, like those found on the San Antonio retablo, not only in iconography but also design elements. Indeed, a subtle difference exists between the sculpted cord, which does not maintain its presence along the edges of the whole retablo. This differs from La Soledad and Santa Teresita. On these altarpieces the cord framing device is consistent in shape and form across the entirety of both works. The differences may be moot, but they encourage further contemplation about possibilities that the upper tympanum on the San Antonio retablo may be from a now-lost retablo to San Ildefonso. During the early twentieth-century restoration program, the top could have been easily added to the retablo. The San Antonio retablo could have not had a top to allow for the viewing of the frescoes in the niche's arch. Feasibly by the early 1900s, the four-hundred-year-old paintings would have been in disrepair, thus providing a suitable home for the fragmented piece dedicated to San Ildefonso. Some clarity could be gained from the restoration programs conducted in the early 2000s, but unfortunately these reports have not circulated or been extrapolated upon in academic writing. Despite this, we must begin to rethink our analyses of the retablos as well as the visual culture of colonial Yucatán. In revaluating our understanding 
of Yucatecan Art History, we must take a closer look at the larger historiography of the peninsula, while also exploring ideas of cultural memory. Indeed, within a few generations of the destruction of many Yucatecan churches, churches were rebuilt or renovated. The local communities quickly absorbed and embraced these new works into their collective identities. The retablos are now a part of the local heritages and cultures of Mani and Teabo.

Funding: This research was funded by the University of Western Ontario, Dean's Research Grants.

Institutional Review Board Statement: Not applicable.

Informed Consent Statement: Not applicable.

Data Availability Statement: Not applicable.

Acknowledgments: I would like the thank the reviewers and editors. Likewise, I extend my sincere gratitude to the librarians at UWO and the Universidad Autónoma de Yucatán for their assistance in acquiring rare texts and essays during this global pandemic. Additionally, thank you to Niccolò Brooker and the Instituto Nacional de Antropología e Historia for the use of images.

Conflicts of Interest: The author declares no conflict of interest.

\section{References}

\section{Archival Sources}

Archivo General de Nación (AGN). Castillo, Andrea del. 1572. Autos que sique Dña. Andrea del Castillo, Vda. Del Cap. Francisco Montejo, Conquistador del Provincia de Yucatán, con Pedro Ledezma, sobre el pago de costa de que S.M. le hizo merced por Real Cédula de 18 de mayo de 1572, fechada en Madrid. Section: Hosptial de Jesús. Leg. 464, vol. 264, exp. 4. Mexico City, Mexico.

Archivo Histórico Nacional (AHN). Bienvenida, Lorenzo de. 1548. Sobre la provincia de Yucatán, Carta del franciscano fray Lorenzo de Bienvenida al príncipe D. Felipe, dándole cuenta de algunos asuntos referentes a la provincia de Yucatán y quejándose de abusos, 1548-02-10, Yucatán. Section: Diversos-Colecciones. Leg. 23, n. 16, 2r. Madrid, Spain.

\section{Published Sources}

Alexander, Rani T. Alexander. 2004. Yaxcabá and the Caste War of Yucatán. Albuquerque: University of Mexico Press.

Álvarez, César García. 2001. El simbolismo del grutesco renacentista. León: Universidad de León.

Ancona, Eligio. 1889. Historia de Yucatán, desde la época más remota hasta nuestros días. 4 vols. Mérida: Imprenta de M. Heredia Argüelles. Arrigunaga Peón, Joaquín. 1965. Falso Mayorazgo de la Casa de Montejo. Humanitas 6: 421-37.

Barteet, C. Cody. 2019. Architectural Rhetoric and the Iconography of Authority in Colonial Yucatán: The de Montejo. Visual Culture in Early Modernity. New York and Abingdon: Routledge.

Barteet, C. Cody. Forthcoming. Retablos of Mani: The Convergence of Maya and Spanish Art. In Polychrome Art in the Early Modern World. Edited by Ilenia Colón Mendoza and Lisandra Estevez. New York and Abingdon: Routledge.

Bolañas, Luis Vega, and Justino Fernández. 1945. Catálogo de construcciones religiosas del Estado de Yucatán. Notas de Jorge Ignacio Rubio Mañé. Mexico City: Talleres Gráficos de la Nación, vol. 2.

Bretos, Miguel A. 1992. Iglesias de Yucatán. Portafolio Fotográfico de Christian Rasmussen. Mérida: Producción Editorial Dante, S.A. Bretos, Miguel A. 1987. Arquitectura y arte sacro en Yucatán: 1545-1823. Mérida: Producción Editorial Dante, S.A.

Caramazana Malia, David, and Manuel Romero Bejarano. 2020. Un retablo que hemos de hazer para la dicha iglesia a lo romano. Valencia y Voisín, creadores del retablo mayor de Medina Sidonia (Cádiz). Archivo Español de Arte 93: 205-20. [CrossRef]

Cárdenas Valencia, Francisco de. 1937. Relación Historial Eclesiástica de la provincia de Yucatán de la Nueva España, escrita el año de 1639. Edited by Federico Gómez de Orozco. Mexico City: Antigua librería a Robredo J. Porrúa e hijos. First published 1639.

Ciudad Real, Antonio de. 1976. Tratado curioso y docto de las grandezas de la Nueva España: Relación breve y verdadera de algunas de las muchas cosas de que sucedieron al padre fray Alonso Ponce siendo comisario general de aquellas partes. Edited by Jorge García Lacroix y Víctor García Castillo Farreras. 2 vols. Mexico City: Instituto de Investigaciones Históricos, Universidad Nacional Autónoma de Mexico City. First published 1631.

Cogolludo, Diego López. 1688. Historia de Yucathan. Madrid: Imprenta Real.

Farriss, Nancy M. 1984. Maya Society under Colonial Rule: The Collective Enterprise of Survival. Princeton: Princeton University Press.

Giocondo, Giovanni. 1511. M. Vitruvius per Jocundum solito castigator factus cum figuris et tabula. Vencia: G. da Tridentio. Available online: http:/ / architectura.cesr.univ-tours.fr/Traite/Images/CESR_2994Index.asp (accessed on 29 January 2021).

Gómez-Ferrer, Mercedes, and Juan Corbalán de Celis. 2012. Un contrato inédito de Juan de Juanes. El retablo de la Cofradía de la Sangre de Cristo de Valencia (1539). Archivo Español de Arte 85: 1-16. [CrossRef]

Hunt, Marta Espejo-Ponce. 1974. Colonial Yucatan: Town and Region in the Seventeenth Century. Ph.D. thesis, University California, Los Angeles, CA, USA.

Landa, Diego de. 1566. Relación de las cosas de Yucatán. M-RAH, 9/5153. Madrid: Real Academia del la Historia Madrid. 
Lizana, Bernardo de. 1983. Historia de Yucatán: Devocionario de Nstr. Sra. de Izmal y Conquista Espiritual. Mexico City: Imprenta del Museo Nacional. First Published 1633.

Mainar, Jesús Criado. 2017. Martín de Mezquita, Tesorero de al catedral de Nuestra Señora de la Huerta de Tarazona (Zaragoza). Merindad de Tudela: Revista del Centro de Estudios 25: 9-32.

McAndrew, John, and Manuel Toussaint. 1942. Tecali, Zacatlan, and the Renacimiento Purista in Mexico. The Art Bulletin $24: 311-25$.

Menéndez Rodríguez, Hernán. 1995. Iglesia y poder, proyectos sociales, alianzas políticas y económicas en Yucatán (1857-1917). Mexico City: Colección Regiones, CONACULTA.

Mestre, Miguel. 1688. Vida y milagros del glorioso San Antonio de Padua, Sol brillante de la iglesia, lustre de la región Seráfica, Gloriad de Portugal, Honor de España, Tesoro de Italia, Terror del Infierno, Martillo perpetuo de la herejía, entre los Santos por Excelencia el Milagrero. Barcelona: Publicado por Imp. De la Viuda e Hijo de Sierra.

Nieto Alcaide, Victor, Alfredo J. Morales, and Fernando Checa Cremades. 2009. Arquitectura del Renacimiento en España, 1488-1599. Madrid: Ediciones Cátedra.

Oviedo y Valdez, Gonzalo Fernández de. 1851. Historia general y natural de las Indias. Madrid: Real Academia de la Historia.

Padrón Mérida, Aida. 1993. Lorenzo de Ávila y Blas de Oña: Autores del retablo de Santa María en Pajares. Archivo Español de Arte 66: 11-33.

Pascacio Guillén, Bertha. 2021. 'Son retablos de talla extremados': Los colaterales de columnas antropomorfas en el Yucatán virreinal. Fronteras de la Historia 26: 170-98. [CrossRef]

Perry, Richard, and Rosalind Perry. 1988. Maya Missions: Exploring the Spanish Colonial Churches of Yucatan. Santa Barbara: Espadaña Press.

Quezada, Sergio Aguayo. 1993. Pueblos y Cacique Yucatecos, 1550-1580. Mexico City: El Colegio de Mexico City.

Quezada, Sergio Aguayo. 2014. Maya Lords and Lordship: The Formation of Colonial Society in Yucatán, 1350-1600. Translated by Terry Rugeley. Norman: University of Oklahoma Press.

Restall, Matthew. 2001. The People of the Patio: Ethnohistorical Evidence of Yucatec Maya Royal Courts. In Royal Courts of the Ancient Maya. Edited by Takeshi Inomata and Stephen D. Houston. Boulder: Westview Press, vol. 2, pp. 354-57.

Rubio Mañe, Jorge Ignacio. 1941. El Excmo. Sr. Dr. D. Martin Tritschler y Córdova, Primer Arzobispo de Yucatán. Edición especial de la junta organizadora del Jubileo Sacerdotal del Excm o. Sr. Arzobispo de Yucatán Dr. D. Martin Tritschler y Córdova. Mexico City: Sobretiros de ABSIDE.

Sánchez de Aguilar, Pedro. 1639. Informe contra los adoradores de ídolos del Obispado de Yucatán: Año de 1639. Available online: http:/ / www.cervantesvirtual.com/nd/ark:/59851/bmc1c1v7 (accessed on 29 January 2021).

Schenone, Héctor H. 1992. Iconografia del arte colonial: Los Santos. 2 vols. Buenos Aires: Fundación Tarea.

Stephens, John L. 1848. Incidents of Travel in Yucatán. 2 vols. New York: Harper \& Brothers.

Suárez Castro, María de Guadalupe. 2014. El convento de Maní, Yucatán, en 1588. Boletín de Monumentos Históricos 31: 78-92.

Vanoye Carlo, Ana Raquel. 2011. Esbozo de la historia de la pintura mural virreinal de Yucatán a través del Convento de Santa Clara de Asís en Dzidzantún. Ph.D. thesis, Universidad Nacional Autónoma de Mexico City, Mexico City, Mexico.

Vanoye Carlo, Ana Raquel. 2016. La pintura mural del convento de Santa Clara de Asís en Dzidzantún, Yucatán. Generalidades sobre la ejecución de cuatro diferentes etapas. Anales del Instituto de Investigaciones Estéticas 38: 217-73. [CrossRef]

Vargaslugo, Elisa. 1988. Los retablos novohispanos en opinión de don Diego Angulo Íñiguez. Anales del Instituto de Investigaciones Estéticas 15: 60-77. [CrossRef]

Vila Jato, Maria Dolores. 1987. El retablo renacentista en Galicia. Imafronte 3-4-5: 33-49. 